\title{
Conditional Conservatism of Aggregate Accounting Earnings
}

\author{
Dongkuk Lim ${ }^{1} \&$ Kenneth Zheng ${ }^{2}$ \\ ${ }^{1}$ Assistant Professor, Department of Accounting, College of Business, Idaho State University, Pocatello, ID, USA \\ ${ }^{2}$ Assistant Professor, Department of Accounting and Law, School of Management, University at Buffalo, The State \\ University of New York, Buffalo, NY, USA \\ Correspondence: Dongkuk Lim, Department of Accounting, College of Business, Idaho State University, 921 South \\ $8^{\text {th }}$ Avenue, Stop 8020, Pocatello, ID 83209, USA. Tel: 1-208-282-2975 E-mail: limdong@isu.edu
}

Received: October 7, 2014

Accepted: October 29, 2014

Online Published: October 30, 2014

doi:10.5430/afr.v3n4p115

URL: http://dx.doi.org/10.5430/afr.v3n4p115

\begin{abstract}
Using both the Basu (1997) model and the Ball and Shivakumar (2006) models, we examine whether or not conditional conservatism is observed at the aggregate level. We find some evidence consistent with conditional accounting conservatism at the aggregate level. Our results show that the slope coefficient on the interaction variable measuring the difference in sensitivity of aggregate accounting earnings to equal-weighted aggregate stock market returns is approximately three times as high in periods with negative market returns as is in periods with positive market returns. Our results also demonstrate that the inclusion of macroeconomic indicators and discount rate variables into the conditional conservatism models improves model specification significantly. For example, when equal-weighted return is used as the gain or loss proxy, the inclusion of macroeconomic indicators and discount rate proxies in the regression model increases the adjusted $R^{2}$ from $5 \%$ to $53 \%$. Based on the empirical evidence from this study, we recommend that researchers who study the fundamental characteristics of accounting information in the context of aggregate accounting earnings include both macroeconomic indicators and discount rate variables as explanatory variables in their regression models in order to improve model specification.
\end{abstract}

Keywords: Aggregate earnings, Conditional conservatism, Aggregate cash flows

\section{Introduction}

Prior studies provide some empirical evidence regarding how market participants react to aggregate accounting earnings news (i.e., Kothari, Lewellen, \& Warner, 2006; Anilowski, Feng, \& Skinner, 2007; Cready \& Gurun, 2010; Patatoukas, 2014). These studies speculate that the stock market's response to aggregate accounting earnings news is due to the fact that aggregate accounting earnings provide information regarding the macroeconomy. For example, Kothari, Lewellen, and Warner (2006) claim that aggregate earnings changes are correlated with contemporaneous value news which may cause investors to revise their expectations regarding discount rates. Patatoukas (2014) suggests that the relation between aggregate accounting earnings and stock market valuation is complicated by the fact that stock market prices are very sensitive to even small revisions in investors' expectations concerning discount rates. He specifically demonstrates that an increase in expected future cash flows is positively related to valuation, while an increase in discount rate is negatively related to the firm's value. However, these studies primarily focus on investigating the relationship between aggregate accounting earnings and expected future cash flows or discount rates, i.e., whether or not aggregate accounting earnings data can provide new information to the market in terms of expected future cash flows and discount rates, rather than examining the fundamental characteristics of financial reporting information at the aggregate level. We investigate whether or not the conditional conservatism which is widely observed in the individual firm level is also observed in the aggregate level.

Basu (1997) interprets accounting conservatism as capturing accountants' tendency to require a higher degree of verification for recognizing good news than bad news in financial statements (pp. 4). Similarly, Watts (2003) defines conditional accounting conservatism as the asymmetric verifiability required for recognition of profits versus losses (pp. 208). The result of conditional conservatism is that losses are reflected in net income more quickly than gains. Watts (2003) attributes the demand for conditional accounting conservatism to explanations related to contracting, shareholder litigation, taxation, and accounting regulation. It follows that when a firm is faced with contracting or shareholder litigation concerns then it will likely adopt conservative accounting.

Given this firm-level conditional accounting conservatism, one can draw an analogy between the demand for 
conditional accounting conservatism at the firm level and that at the aggregate level. Each publicly traded company is required to provide its earnings figures periodically, and aggregating such earnings numbers is naturally expected to provide timely information concerning aggregate earnings and the macroeconomy. This consequently affects stock market returns (refer to Shivakumar, 2007). When the market as a whole incurs an economic loss it increases the need for debt holders to make reassessments regarding the lower bounds of their claims. Bad economic times may trigger firms to re-estimate the useful lives of tangible assets and incur larger impairment expenses. An efficient market will then expect and require that aggregate earnings recognize losses in economic downturns in a timelier manner than gains in economic booms.

Although these expectations seem reasonable, one may still expect to observe no conditional accounting conservatism at the aggregate level. First, prior studies find that aggregate earnings exhibit different traits than firm-level earnings. Kothari, Lewellen, and Warner (2006) investigate the earnings-return relation at the aggregate level, documenting a negative correlation between market returns and aggregate earnings news. Hirshleifer, Hou, and Teoh (2009) also show that the negative aggregate earnings-return correlation mainly derives from a negative relation between innovations in aggregate accruals and market returns. Both studies speculate that the flipped correlation sign between returns and earnings (or accruals) at the aggregate level results from the fact that aggregate earnings (or aggregate accruals) contain information regarding discount rate changes.

Second, prior studies suspect that the earnings aggregation process may cancel out the signs of events occurring during each period. Givoly, Hayn, and Natarajan (2007) identify certain characteristics of the information environment unrelated to conservatism that affect Basu's (1997) conditional accounting conservatism as measured by differential earnings timeliness. They find that the differential timeliness measure is sensitive to the degree of uniformity in the news content during a given period. Specifically, if a measurement period is dominated by same-sign events then it is more likely to find a significant positive coefficient on return when interacted with the dummy variable that is a proxy for a gain or loss. The aggregation procedure may therefore have combined opposite-sign events, attenuating the positive coefficient.

Third, prior finance and accounting literature attempt but have not yet found conditional accounting conservatism at the aggregate level. Jorgensen, $\mathrm{Li}$, and Sadka (2009) investigate whether or not accounting conservatism changes across different accounting regimes. Using equal-weighted and value-weighted aggregate returns calculated based on all individual stocks for each year in their sampled period, they find no evidence of conditional accounting conservatism at the aggregate level.

The current literature does not provide any empirical support on conditional accounting conservatism at the aggregate level. In this study, we accordingly investigate conditional conservatism at the aggregate level, i.e., the relation between aggregate market returns and aggregate earnings, using different conditional conservatism models as well as including macroeconomic indicators and discount rate variables in these models to explain this relationship.

We address our research question by following prior studies that aggregate firm-level data for further analyses (refer to Kothari et al. 2006; Jorgensen et al. 2009; Cready \& Gurum, 2010). Our sample period spans over the years from 1963 to 2009. We collect accounting data along with equal- and value-weighted market return data from the CRSP/Compustat Merged database and CRSP indices, respectively. We limit our sample to firms with fiscal years ending in December only in order to increase comparability with earlier studies. In order to be consistent with Cready and Gurun (2010), we also limit our sample to firm year observations with stock prices between US $\$ 5$ and US $\$ 10,000$.

To test our predictions, we first use both the Basu (1997) and the Ball and Shivakumar (2006) conditional conservatism models to examine conditional accounting conservatism at the aggregate level. Our results support our predictions by showing that the sensitivity of aggregate accountings to equal-weighted aggregate market returns is approximately three times $(3.025=[0.162+0.080] / 0.080)$ as high in periods with negative market returns as is in periods with positive market returns (refer to Panel A of Table 3). Moreover, we add macroeconomic indicators and discount rate variables to both models because these factors have been shown to play a role in the aggregate earnings-returns relation. Our results show that the inclusion of macroeconomic indicators and discount rate variables in the conditional conservatism models improves the model specification and as a result $R^{2}$ increases from $5 \%$ in panel 3 of Table 3 to $53 \%$ in panel A of Table 5. Our findings are consistent with the documentation of firm-level conditional conservatism in prior studies. These prior papers argue that an efficient market requires that aggregate earnings recognize losses in a timelier manner than gains (refer to Shivakuma $2007 \& 2010$ ).

This study contributes to the literature as follows. First, we find evidence of conditional accounting conservatism at 
the aggregate level. Both the Basu (1997) and some of the Ball and Shivakumar (2006) models suggest that conditional accounting conservatism may be present at the aggregate level. Second, we demonstrate that adding the macroeconomic indicators and discount rate variables in the "reverse regression models" of accounting earnings and returns at the aggregate level improves the model specification significantly. More importantly, our findings demonstrate that conditional accounting conservatism remains visible even after controlling for the relationship between the discount rate and aggregate returns. Third, our results add to the aggregate studies by showing that aggregate accruals are timelier in recognizing bad versus good economic news, suggesting that firms do manage accounting accruals in response to market-wide undervaluation (refer to Ball and Shivakumar, 2006).

This paper is organized as follows. Section 2 discusses the prior literature on the conditional accounting conservatism and aggregate earnings-return relation at both the firm- and aggregate-level and develops our hypotheses. Section 3 describes the sample and research design. Section 4 provides empirical results, and section 5 concludes.

\section{Literature Review and Hypothesis Development}

\subsection{Firm-Level Conservatism Studies}

There are two different forms of accounting conservatism - unconditional and conditional conservatism. One example of unconditional accounting conservatism is the excessive depreciation recognition concerning difficult-to-verify information and results in downwardly biased reported accounting numbers. An example of conditional accounting conservatism is the practice of impairment rules applied after difficult-to-verify news occurs (Qiang, 2007). Bliss (1924) interprets accounting conservatism as "anticipates no profits but anticipates all losses." Basu (1997) interprets conditional conservatism as the systematic differences between the bad news and good news periods during which accounting earnings incorporate the news. Using negative and positive unexpected annual stock returns as a proxy for bad and good news, respectively, he finds that accounting earnings recognize bad news in a timelier fashion than good news.

Ball and Shivakumar (2006) apply this notion of conditional accounting conservatism in testing whether or not accruals recognize gains and losses in an asymmetrically-timely manner. They argue that the relation between cash flows and accruals cannot be linear because the recognition of gains and losses is asymmetric. They also contend that earnings is a more efficient performance measure relative to cash flows for contracting purposes because of the role accruals play in ameliorating the noise in cash flows. They argue that the asymmetric gain and loss recognition role of accruals should exhibit a positive association between cash flows and accruals whereas the noise-reduction role of accruals should manifest itself in a negative correlation between cash flows and accruals.

Watts (2003) attributes the demand for accounting conservatism to explanations related to contracting, litigation, taxation, and regulation. On the contracting role of conservatism Zhang (2008) finds that conservatism provides lenders with ex post benefits through the timely signaling of default risk and ex ante benefits through lower interest rates. LaFond and Roychowdhury (2008) argue that conservatism mitigates the agency problem arising from the separation of ownership and control. They find that as managerial ownership in a firm increases, i.e., when the agency problem is less severe, the Basu (1997) asymmetric timeliness coefficient becomes less positive, i.e., less conservatism is observed.

Lobo and Zhou (2006) investigate the change in financial reporting conservatism following the Sarbanes-Oxley Act of 2002 and find evidence consistent with the demand of conservatism due to litigation risk. They document that as the litigation risk related to executives' certification of financial reports increases following the SOX firms report lower discretionary accruals. Additionally, the interaction variable in Basu's (1997) model measuring the asymmetric timeliness for the recognition of bad news versus good news also increases.

The regulation explanation finds regulators and standard setters induce reporting conservatism by imposing regulatory costs on firms, while the taxation hypothesis reports that firms demand conservative accounting in order to defer taxes (Qiang, 2007). When firms are faced with either contracting or shareholder litigation concerns, they will likely adopt conservative accounting.

\subsection{Aggregate-Level Accounting Earnings and Stock Market Studies}

A recent stream of research inquires into whether or not certain accounting phenomena appear at the aggregate level. A pioneer study by Kothari, Lewellen, and Warner (2006) examines post-earnings announcement drift at the aggregate level. Contrary to the firm-level findings that stock returns drift in the direction of earnings surprises for up to three quarters following the earnings announcement, Kothari et al. (2006) find that aggregate market returns are unrelated to past aggregate earnings but are negatively correlated with concurrent aggregate earnings (refer to 
Bernard and Thomas, 1990). They argue that a contemporaneous negative relation between aggregate accounting earnings and market returns is consistent with the discount rate implications of aggregate earnings, while the positive relation at the firm level suggests that firm earnings are dominated by cash flow news. They also find that earnings growth is strongly correlated with several discount rates proxies including changes in T-bill rates, changes in the term structure slope, and changes in the yield spread between low- and high-grade corporate bonds. They speculate that this discount rate implication in aggregate earnings and aggregate accruals can lead to a different finding when we use conservatism models for aggregate earnings versus firm earnings. Patatoukas (2014) uses a US stock market sample from 1981 to 2009 showing that the relation between aggregate accounting earnings and discount rates is due to the fact that aggregate accounting earnings are tied to news regarding the real riskless rate, expected inflation, and expected equity risk premium.

Hirshleifer, Hou, and Teoh (2009) study the accrual anomaly at the aggregate level. Previous firm-level studies find that investors overestimate the implications of accruals and underestimate the implications of cash flows for future earnings assessment (i.e., Sloan, 1996). Accruals are therefore a negative predictor of abnormal stock returns. Hirshleifer et al. (2009) show that aggregate accruals are a strong positive time series predictor for aggregate market returns, while innovations in accruals are negatively and contemporaneously correlated with aggregate returns. These findings suggest that innovations in aggregate accruals and cash flows either contain information regarding changes in discount rates or that firms manage earnings in response to market-wide undervaluation (Hirshleifer et al., 2009).

It is therefore reasonable to expect to observe conditional accounting conservatism at the aggregate level (i.e., Shivakumar, 2007). Consequently, we find that prior aggregate-level studies investigating the relation between aggregate accounting earnings and stock market valuation may have implications for studying aggregate accounting conservatism as well. However, earlier studies that examine the aggregate earnings-returns relation (Kothari et al., 2006) or aggregation bias (Givoly et al., 2007) have not tested the fundamental characteristics of reported accounting information such as conditional accounting conservatism at the aggregate level. Jorgensen et al. (2009) attempt to document conditional accounting conservatism at the aggregate level but their results are insignificant using within-sample aggregate returns.

\subsection{Hypothesis Development}

Qiang (2007) points out that both the contracting and litigation explanations for accounting conservatism may induce conditional conservatism at the firm level. One may therefore anticipate to observe conditional conservatism at the aggregate level as well (i.e., Shivakumar, 2007). When the stock market is dominated by bad news, debt holders are more likely to demand assessment information for the liquidation value of their debts. Firms may also be forced to incur large impairment losses on their inventories and tangible and intangible assets. Poor stock performance when the market suffers from a decline also increases the litigation risks, which in turn leads firms to report more conservatively. Thus, we expect to see aggregate accounting earnings respond to market losses in a timelier manner than to market expansion. Our hypotheses below are stated in the alternative form:

H1a: Aggregate accounting earnings recognize market losses and gains in an asymmetrically timely manner.

H1b: Aggregate accruals recognize market losses and gains in an asymmetrically timely manner.

Prior literature documents that aggregate accounting earnings have implications for macroeconomic variables such as inflation, expected future cash flows, and discount rate news (i.e., Kothari et al., 2006; Jorgensen et al., 2009; Patatoukas, 2014). Ignoring macroeconomic variables and discount rates in regression models may result in lower $R^{2}$ due to poor model specification when aggregate accounting earnings are used as the dependent variable and aggregate returns as an independent variable in the regression. In particular, omitting the discount rate proxy in the models may introduce a correlated omitted variable problem in the model. We therefore expect to observe an improvement in the model specification once we introduce the discount rate variables alongside the macroeconomic indicators in the conditional conservatism models.

H2: Including discount rate proxy variables and macroeconomic variables in the conditional conservatism models improves the model specification at the aggregate level.

\section{Sample and Research Design}

We collect annual financial and accounting data spanning from the years 1963 to 2009 . We download the equal- and value-weighted market return data from the CRSP indices. We retrieve the accounting data from the CRSP/Compustat merged database, restricting our sample to firm-year observations for which the earnings per share before extraordinary items as well as operating income are all available. Similar to Jorgensen et al. (2009), we limit our sample to firm-year observations with a December fiscal year end. Consistent with Cready and Gurun (2010), we 
exclude firm years with stock prices lower than US $\$ 5$ or higher than US $\$ 10,000$. If any data on current assets, cash, current liabilities, short-term debt, taxes payable, depreciation, revenue, or gross property, plants, and equipment are missing then we assign a value of zero to these items.

Following Kothari et al. (2006) we calculate both earnings and earnings changes for the overall market in three different ways referred to as "aggregate," "equal-weighted," and "value-weighted." The aggregate series is the cross-sectional sum of either earnings or earnings changes for all firms within the sample scaled by the cross-sectional sum of lagged market equity ( $E p$ or $d E p$ ), lagged book equity ( $E b$ or $d E b$ ), or lagged earnings ( $E e$ or $d E e$ ). The equal- and value-weighted measures are denoted with a suffix _ew and_vw, respectively. Consistent with prior studies, we also exclude stocks whose $d E p$ ratios fall into the top and bottom $1 \%$ of their annual distributions (i.e., Kothari et al., 2006).

We follow Sloan (1996) and calculate accruals as follows:

$$
\begin{aligned}
& \text { Accruals }=(\triangle C A-\triangle \text { Cash })-(\triangle C L-\triangle S T D-\triangle T P)-D e p \quad \text { Equation (1) } \\
& \text { Where } \quad \triangle C A=\text { change in current assets, } \\
& \Delta \text { Cash = change in cash/cash equivalents, } \\
& \triangle C L=\text { change in current liabilities, } \\
& \triangle S T D=\text { change in debt included in current liabilities, } \\
& \triangle T P=\text { change in income taxes payable, } \\
& \text { Dep }=\text { depreciation and amortization expense. }
\end{aligned}
$$

Similar to Jorgensen et al. (2009), we use operating income as earnings in the accruals model. We calculate cash flow as the difference between operating income and accrual. We use the balance sheet numbers to calculate accruals and cash flows because the data from cash flow statements are not available for approximately half of our sample period (Hribar \& Collins, 2002). We deflate accruals, cash flows, revenues, and gross property, plant, and equipment by average total assets. We calculate the equal-weighted and value-weighted aggregate accrual, cash flow, change in revenue, and gross property, plant, and equipment similarly to the equal-weighted and value-weighted aggregate earnings. Our final sample consists of CRSP returns and aggregate Compustat accounting data between the years 1963 and 2009.

In order to test Hypothesis 1, we apply the Basu (1997) and Ball and Shivakumar (2006) models to the aggregate accounting earnings and return data:

$$
\begin{aligned}
& E_{t} \text { or } d E_{t}=a_{0}+a_{1} D R_{t}+a_{2} R_{t}+a_{3} R_{t} \times D R_{t} \quad \text { Equation (2) } \\
& \text { where } \quad E_{t}=\text { aggregate earnings during year t, } \\
& d E_{t}=\text { aggregate change in earnings during year } \mathrm{t} \text {, } \\
& R_{t}=\text { CRSP equal- or value-weighted market return during year t, } \\
& D R_{t}=\text { a dummy variable which equals } 1 \text { if } R_{t}<0 \text {. } \\
& A c c_{t}=b_{0}+b_{1} X_{t}+b_{2} \operatorname{Var}_{t}+b_{3} d \operatorname{Var}_{t}+b_{4} d \operatorname{Var}_{t} \times \operatorname{Var}_{t}+v_{t} \quad \text { Equation (3) } \\
& \text { where } \quad A c c_{t}=\text { aggregate accrual during year } \mathrm{t} \text {, } \\
& X_{t}=\text { aggregate-level set of independent variables that accruals models in the literature (i.e., } \\
& \text { Jones, 1991; Dechow \& Dichev, 2002), } \\
& \operatorname{Var}_{t}=\text { a proxy for gain or loss, } \\
& d \operatorname{Var}_{t}=\mathrm{a}(0,1) \text { dummy variable that equals } 1 \text { if } \operatorname{Var}_{t}<0 .
\end{aligned}
$$

We expect $a_{3}$ (Eq. 2) and $b_{4}$ (Eq. 3) measuring the difference in the sensitivity of aggregate accounting earnings to negative stock market returns relative to positive stock market returns to be positive and significant, which would suggest that aggregate accounting earnings (and aggregate accruals) are conditionally conservative.

We test Hypothesis 2 by including macroeconomic indicators and discount rate proxies in equations (2) and (3). Following Kothari et al. (2006), we use GDP, CONS, and IPROD as macroeconomic indicators. GDP and CONS are per capita growth rates for real gross domestic product and personal consumption. IPROD is growth in industrial production. For discount rate proxies we use the four-quarter change in T-bill, TERM, and DEF. T-bill is the three-month T-bill rate. TERM is the yield spread between 10-year T-notes and three-month T-bill rates. $D E F$ is the 
yield spread between Baa- and Aaa-rated corporate bonds.

We expect the model specification for Equations (2) and (3) to improve, thus a higher likelihood of observing conditional conservatism using the aggregate data once macroeconomic indicators and discount rate variables are included in the models.

\section{Empirical Results}

Table 1 presents the descriptive statistics for the aggregate-level variables. In panel A, the mean (median) of the equal- and value-weighted market returns are $15.1 \%(11.8 \%)$ and $9 \%(12.1 \%)$, consistent with the $3.82 \%$ and $3.34 \%$ quarterly market returns reported by Kothari et al. (2006). The mean (median) of the aggregate, equal-weighted, and value-weighted earnings are $7.1 \%(6.6 \%), 7.4 \%(6 \%)$, and $6.3 \%(6.5 \%)$ respectively, when aggregate earnings are scaled by the cross-sectional sum of lagged market equity. In panel B, the mean and median of equal-weighted accruals are $-1.7 \%$ and $-1.9 \%$ while the mean and median of value-weighted accruals are $-4.1 \%$ and $-3.1 \%$, suggesting that a marked difference exists between the distributions of these two measures. While the maximum for equal-weighted accruals is $1.4 \%$, the maximum for value-weighted accruals is $-1.1 \%$.

Table 1. Descriptive statistics

Panel A. Aggregate returns and earnings, 1963-2009

\begin{tabular}{|c|c|c|c|c|c|}
\hline Variable & Mean & Median & Std Dev & Minimum & Maximum \\
\hline$R_{t}^{e w}$ & 0.151 & 0.118 & 0.272 & -0.408 & 0.768 \\
\hline$R_{t}^{v w}$ & 0.090 & 0.121 & 0.188 & -0.387 & 0.456 \\
\hline$e p \_a g g$ & 0.071 & 0.066 & 0.036 & 0.019 & 0.175 \\
\hline$e b \_a g g$ & 0.115 & 0.123 & 0.026 & 0.061 & 0.197 \\
\hline$e e \_a g g$ & 0.996 & 1.216 & 0.251 & 0.411 & 1.796 \\
\hline$d E p \_a g g$ & 0.004 & 0.007 & 0.014 & -0.032 & 0.051 \\
\hline$d E b \_a g g$ & 0.009 & 0.012 & 0.026 & -0.062 & 0.059 \\
\hline dEe_agg & 0.081 & 0.122 & 0.232 & -0.576 & 0.812 \\
\hline$e p \_e w$ & 0.074 & 0.060 & 0.042 & 0.017 & 0.186 \\
\hline$e b \_e w$ & 0.021 & 0.020 & 0.022 & -0.021 & 0.064 \\
\hline ee_ew & 1.127 & 1.115 & 0.231 & 0.541 & 1.572 \\
\hline dEp_ew & 0.002 & 0.005 & 0.017 & -0.045 & 0.037 \\
\hline$d E b \_e w$ & 0.013 & 0.018 & 0.034 & -0.114 & 0.095 \\
\hline dEe_ew & 0.066 & 0.069 & 0.319 & -0.545 & 0.599 \\
\hline$e p \_v w$ & 0.063 & 0.065 & 0.037 & 0.016 & 0.162 \\
\hline$e b \_v w$ & 0.005 & 0.004 & 0.013 & 0.000 & 0.078 \\
\hline$e e \_v w$ & 1.112 & 1.129 & 0.441 & 0.093 & 2.081 \\
\hline$d E p \_v w$ & 0.001 & 0.001 & 0.012 & -0.023 & 0.031 \\
\hline$d E b \_v w$ & 0.021 & 0.022 & 0.031 & -0.066 & 0.063 \\
\hline$d E e_{-} v w$ & 0.122 & 0.121 & 0.414 & -0.901 & 0.918 \\
\hline
\end{tabular}

Note. This table, Panel A, presents summary statistics of key variables. $R_{t}^{\text {ew }}$ measures the equal-weighted buy and hold market return from April of year $\mathrm{t}$ to March of year $\mathrm{t}+1 . R_{t}^{v w}$ measures the value-weighted buy and hold market return from April of year $\mathrm{t}$ to March of year $\mathrm{t}+1$. Ep is the cross-sectional sum of earnings for all firms in the sample, scaled by the cross sectional sum of lagged market equity. $E b$ (or $d E b$ ) is the cross-sectional sum of earnings (or earnings changes) for all firms in the sample, scaled by the cross sectional sum of lagged book value of equity. Ee (or $d E e$ ) is the cross-sectional sum of earnings (or earnings changes) for all firms in the sample, scaled by the cross sectional sum of lagged earnings. Following Kothari et al. (2006), we measure the portfolio values in three ways: The "Aggregate," denoted with a suffix _agg, numbers equal the sum of the numerator divided by the sum of the denominator for firms in the portfolio. The "Equal weighted" and "Value weighted, denoted with a suffix _ew and _vw respectively, numbers are instead averages of firm-level ratios, beginning with per share numbers. Our sample 
consists of firms with December fiscal year-end and we exclude stocks whose $d E p$ ratios fall in the top and bottom $1 \%$ of their annual distributions.

Panel B. Aggregate variables for the accruals models

\begin{tabular}{lrrrrr}
\hline Variable & Mean & Median & Std Dev & Minimum & Maximum \\
\hline$a c c \_e w$ & -0.017 & -0.019 & 0.018 & -0.076 & 0.014 \\
$c f \_e w$ & 0.121 & 0.131 & 0.027 & 0.072 & 0.171 \\
$d C F \_e w$ & 0.002 & 0.001 & 0.018 & -0.041 & 0.051 \\
$c f \_e w_{t-1}$ & 0.112 & 0.124 & 0.021 & 0.055 & 0.176 \\
$c f \_e w_{t+1}$ & 0.121 & 0.123 & 0.021 & 0.035 & 0.144 \\
$d R e v \_e w$ & 0.122 & 0.102 & 0.055 & -0.006 & 0.302 \\
gppe_ew & 0.719 & 0.699 & 0.162 & 0.331 & 1.127 \\
$a c c \_v w$ & -0.041 & -0.031 & 0.010 & -0.082 & -0.011 \\
$c f \_v w$ & 0.171 & 0.153 & 0.031 & 0.087 & 0.241 \\
$d C F \_v w$ & 0.000 & -0.001 & 0.018 & -0.044 & 0.041 \\
$c f \_v w_{t-1}$ & 0.171 & 0.162 & 0.033 & 0.053 & 0.311 \\
$c f \_v w_{t+1}$ & 0.161 & 0.155 & 0.042 & 0.001 & 0.233 \\
$d R e v \_v w$ & 0.076 & 0.080 & 0.056 & -0.005 & 0.312 \\
$g p p e \_v w$ & 0.733 & 0.781 & 0.179 & 0.299 & 1.318 \\
\hline
\end{tabular}

Note. This table, Panel B, presents summary statistics of key variables used in the accrual models. Acc is the aggregate accruals, and $c f$ is the aggregate cash flows, using the balance sheet approach (refer Hribar \& Collins, 2002). The equal-weighted and value-weighted variables, i.e., $A c c \_e w, A c c \_v w, c f \_e w$, and $c f \_v w$, are calculated in the same way we calculate $E e_{-} e w$ and $E e_{-} v w . d C F \_e w$ and $d C F_{-} v w$ are the aggregate cash flows change, equal- and value-weighted respectively. $d R e v$ is the aggregate revenue change and gppe is the aggregate gross PP\&E. The equal-weighted and value-weighted variables, i.e., $d R e v \_e w, d R e v \_v w, g p p e \_e w$, and $g p p e_{-} v w$, are calculated in the same way we calculate $E e_{-} e w$ and $E e_{-} v w$. Same as the Panel A, December-ending and $d E p$ ratios rules are applied in sample filtering.

Table 2 shows the simple correlations among the key aggregate-level variables of interest. We do not report alternative earnings measures (i.e., $E b, E e, d E b, d E e$ ) and some variables in the accruals models in order to conserve space. Each equal-weighted variable is correlated with its value-weighted counterpart except for the correlations between $d C F_{-} e w$ and $d C F_{-} v w$. This suggests that the differences in the distributions for $d C F_{-} e w$ and $d C_{-} v w$ may make the accruals model inferences quite different when one variable is used as the gain/loss proxy versus the other. This may lead to different empirical findings for the equal-weighted and value-weighted Ball and Shivakumar (2006) models. We also find that the correlation between the equal-weighted (value-weighted) market return and change in equal-weighted (value-weighted) earnings is $-0.18(-0.14)$, although it is not significant at the conventional significance level.

Table 2. Correlations among key variables

\begin{tabular}{|c|c|c|c|c|c|c|c|c|c|c|c|c|}
\hline & $R_{t}{ }^{e w}$ & $R_{t}{ }^{v w}$ & $e p \_e w$ & $d E p \_e w$ & $e p \_v w$ & $d E p \_v w$ & acc_ew & \multicolumn{2}{|c|}{$d C F_{e} e w$} & $a c c \_v w$ & \multicolumn{2}{|c|}{$d C F \_v w$} \\
\hline$R_{t}^{e w}$ & & $0.75 * * *$ & 0.13 & -0.18 & 0.21 & -0.11 & 0.10 & & -0.09 & 0.10 & & -0.21 \\
\hline$R_{t}{ }^{\nu w}$ & $0.73 * * *$ & & 0.10 & -0.17 & 0.27 & -0.14 & -0.08 & & 0.01 & 0.01 & & -0.25 \\
\hline$e p \_e w$ & 0.11 & 0.09 & & $0.31 *$ & $0.85^{* *}$ & 0.21 & 0.61 & ** & -0.14 & 0.32 & $* *$ & 0.00 \\
\hline$d E p \_e w$ & -0.16 & -0.13 & $0.22 *$ & & 0.21 & $1.01^{* *}$ & 0.41 & ** & 0.10 & 0.52 & $* *$ & 0.12 \\
\hline$e p \_v w$ & $0.26 *$ & $0.26^{* *}$ & $0.72 * *$ & 0.28 & & 0.22 & 0.42 & $* * *$ & -0.11 & 0.22 & & -0.10 \\
\hline$d E p \_v w$ & 0.13 & -0.07 & 0.29 & $0.95 *$ & 0.28 & & 0.35 & $* * *$ & 0.21 & 0.41 & $* * *$ & 0.21 \\
\hline acc_ew & 0.06 & 0.01 & $0.39^{* *}$ & $0.31^{* *}$ & $0.40 * * *$ & $0.26^{*}$ & & & -0.42 & 0.62 & $* * *$ & -0.06 \\
\hline$d C \bar{F} \_w$ & -0.16 & -0.21 & -0.10 & 0.12 & -0.01 & 0.09 & -0.41 & ** & & -0.10 & $* *$ & 0.71 \\
\hline$a c c \_v w$ & 0.07 & 0.08 & $0.41 * *$ & $0.39 * *$ & $0.19 *$ & $0.48 *$ & 0.72 & $* * *$ & -0.27 & & & -0.32 \\
\hline$d C \bar{F} v w$ & -0.23 & -0.29 & 0.04 & 0.31 & -0.02 & 0.12 & 0.01 & & 0.81 & -0.29 & ** & \\
\hline
\end{tabular}

Note. This table shows correlations among key aggregate variables, 1963-2008. $R_{t}^{e w}$ measures the equal-weighted 
buy and hold market return from April of year $\mathrm{t}$ to March of year $\mathrm{t}+1 . R_{t}^{v w}$ measures the value-weighted buy and hold market return from April of year $\mathrm{t}$ to March of year $\mathrm{t}+1$. $E p$ (or $d E p$ ) is the cross-sectional sum of earnings (or earnings changes) for all firms in the sample, scaled by the cross sectional sum of lagged market equity. Following Kothari et al. (2006), we measure the portfolio values in three ways: The "Aggregate," denoted with a suffix agg, numbers equal the sum of the numerator divided by the sum of the denominator for firms in the portfolio. The "Equal weighted" and "Value weighted, denoted with a suffix _ew and _vw respectively, numbers are instead averages of firm-level ratios, beginning with per share numbers. $A c c$ is the aggregate accruals, and $c f$ is the aggregate cash flows, using the balance sheet approach (refer Hribar \& Collins, 2002). The equal-weighted and value-weighted variables, i.e., $A c c \_e w, A c c \_v w, c f \_w$, and $c f \_v w$, are calculated in the same way we calculate $E e \_e w$ and $E e \_v w . d C F \_e w$ and $d C F_{-} v w$ are the aggregate cash flows change, equal- and value-weighted respectively. Our sample consists of firms with December fiscal year-end. We exclude stocks whose $d E p$ ratios fall in the top and bottom $1 \%$ of their annual distributions. Pearson (Spearman) are located in the upper (lower) right (left) corner. ${ }^{* * *}, * *$, and $*$ represent two-tailed significance at the $1 \%, 5 \%$, and $10 \%$ levels, respectively.

Table 3, Panel A (B) reports the results for the basic Basu (1997) model at the aggregate level using equal-weighted (value-weighted) market return as the gain/loss proxy. Panel A shows that seven out of 12 regressions have interaction variable coefficients that are positively significant, consistent with aggregate earnings having the conservatism property. Panel B shows that there is still some evidence of conservatism when the value-weighted market return is used as the gain/loss proxy. Six out of 12 regressions generate positively significant coefficients on the interaction variable.

In general the intercepts in these regressions are significant and positive, suggesting that there is a current recognition of unrealized gains from previous periods that are uncorrelated with current news. It is also worth noting that the adjusted $R^{2}$ from these regressions are low, ranging from -0.01 to 0.10 , suggesting the independent variables explain only a small proportion of the dependent variable's variability. Our finding shows that the Basu (1997) model is able to detect some level of conditional accounting conservatism at the aggregate level.

Table 3. Aggregate-level Basu Models

Panel A: Basu regressions using equal-weighted market return as the gain/loss proxy

\begin{tabular}{|c|c|c|c|c|c|c|c|c|c|c|c|c|}
\hline & \multicolumn{6}{|c|}{ Aggregate } & \multicolumn{6}{|c|}{ EW Earnings } \\
\hline & ep_agg & $e b \_a g g$ & ee_agg & $d E p \_a g g$ & $d E b \_a g g$ & $d E e \_a g g$ & $e p \_e w$ & $e b \_e w$ & ee_ew & $d E p \_e w$ & $d E b \_e w$ & dEe_ew \\
\hline \multirow[t]{2}{*}{ Intercept } & $0.081 * * *$ & $0.129 * *$ & $1.461 * * *$ & $0.010 *$ & 0.012 & 0.061 & $0.071 * * *$ & $0.021 * *$ & $1.116 * * *$ & $0.002 *$ & 0.009 & $0.142 *$ \\
\hline & 8.04 & 11.44 & 14.73 & 1.91 & 1.32 & 1.14 & 5.17 & 5.05 & 12.62 & 1.66 & 1.04 & 1.82 \\
\hline \multirow[t]{2}{*}{$R_{t}{ }^{e w}$} & 0.021 & 0.010 & 0.099 & -0.007 & -0.001 & 0.206 & 0.080 & 0.001 & -0.192 & -0.021 & -0.014 & -0.192 \\
\hline & 1.11 & 0.31 & 0.63 & -0.61 & -0.02 & 0.70 & 1.45 & 0.41 & -1.01 & -1.24 & -0.68 & -1.02 \\
\hline \multirow[t]{2}{*}{$d R_{t}{ }^{e w}$} & 0.021 & 0.029 & $0.301 *$ & 0.017 & $0.041 * *$ & $0.301 *$ & 0.053 & 0.011 & $0.381 * *$ & $0.019 * *$ & 0.013 & 0.219 \\
\hline & 0.81 & 1.24 & 1.90 & 1.51 & 2.22 & 1.66 & 1.52 & 0.41 & 1.99 & 2.06 & 0.26 & 1.62 \\
\hline \multirow[t]{2}{*}{$R_{t}{ }^{e w} \times d_{-} R_{t}{ }^{e w}$} & 0.112 & 0.159 & $1.508 *$ & $0.112 *$ & $0.239 * * *$ & 1.433 & $0.162 * *$ & 0.002 & $1.992 *$ & $0.163 * * *$ & -0.063 & $1.792 * *$ \\
\hline & 1.12 & 1.03 & 1.89 & 1.93 & 2.69 & 1.61 & 1.97 & 0.06 & 1.67 & 3.12 & -0.92 & 2.02 \\
\hline$n$ & 42 & 42 & 42 & 42 & 42 & 42 & 42 & 42 & 42 & 42 & 42 & 42 \\
\hline $\operatorname{Adj} \cdot R^{2}$ & 0.02 & 0.00 & 0.04 & 0.04 & 0.07 & 0.05 & 0.05 & -0.01 & 0.10 & 0.05 & 0.02 & 0.08 \\
\hline
\end{tabular}

$\underline{\text { Panel B: Basu regressions using value-weighted market return as the gain/loss proxy }}$

\begin{tabular}{|c|c|c|c|c|c|c|c|c|c|c|c|c|c|}
\hline & \multicolumn{7}{|c|}{ Aggregate } & \multicolumn{6}{|c|}{ VW Earnings } \\
\hline & $e p \_a g g$ & $e b \_a g g$ & ee $a g g$ & & dEp_agg & $d E b \_a g g$ & $d E e \_a g g$ & $e p \_v w$ & $e b \_v w$ & $e e \_v w$ & $d E p \_v w$ & $d E b \_v w$ & $d E e \_v w$ \\
\hline \multirow[t]{2}{*}{ Intercept } & $0.071 * * *$ & $0.102 * * *$ & 0.978 & $* * *$ & $0.012 * * *$ & 0.012 & 0.081 & $0.071 * * *$ & $0.007 * *$ & $0.827 * *$ & 0.010 & $0.014^{*}$ & $0.201 *$ \\
\hline & 6.53 & 11.74 & 12.75 & & 4.31 & 1.13 & 0.98 & 6.73 & 1.96 & 1.94 & 1.21 & 1.92 & 1.73 \\
\hline \multirow[t]{2}{*}{$R_{t}{ }^{v w}$} & $0.060 *$ & 0.051 & 0.051 & & -0.011 & 0.012 & 0.051 & $0.051 *$ & 0.001 & -0.259 & $-0.022 *$ & 0.011 & -0.526 \\
\hline & 1.69 & 1.21 & 0.26 & & -0.92 & 0.27 & 0.22 & 1.67 & 0.25 & -1.11 & -1.66 & 0.15 & -1.11 \\
\hline \multirow[t]{2}{*}{$d_{-} R_{t}{ }^{v w}$} & 0.032 & $0.041 *$ & 0.122 & & 0.014 & 0.026 & 0.142 & 0.032 & 0.000 & 0.021 & 0.016 & 0.016 & 0.092 \\
\hline & 0.98 & 1.69 & 1.18 & & 1.00 & 1.14 & 1.19 & 1.59 & 0.04 & 0.15 & 0.82 & 0.72 & 0.28 \\
\hline \multirow[t]{2}{*}{$R_{t}{ }^{w w} \times d_{-} R_{t}{ }^{v w}$} & 0.110 & 0.113 & 0.992 & & $0.113 *$ & $0.161 *$ & 0.879 & $0.138 *$ & 0.035 & $1.427 * *$ & $0.092 * *$ & 0.066 & $1.552 * *$ \\
\hline & 1.43 & 1.43 & 1.18 & & 1.92 & 1.68 & 1.42 & 1.72 & 0.82 & 2.07 & 2.01 & 0.57 & 2.21 \\
\hline$n$ & 42 & 42 & 42 & & 42 & 42 & 42 & 42 & 42 & 42 & 42 & 42 & 42 \\
\hline $\operatorname{Adj} . R^{2}$ & 0.05 & 0.02 & 0.01 & & 0.04 & 0.03 & -0.01 & 0.06 & -0.03 & 0.09 & 0.04 & -0.04 & 0.08 \\
\hline
\end{tabular}

Note. This table reports the Basu regression with aggregate-level variables, 1963-2008. $\mathrm{R}_{\mathrm{t}}^{\text {ew }}$ measures the equal-weighted buy and hold market return from April of year $t$ to March of year $t+1 . R_{t}{ }^{v w}$ measures the value-weighted buy and hold market return from April of year $\mathrm{t}$ to March of year $\mathrm{t}+1$. Ep (or $d E p$ ) is the cross-sectional sum of earnings (or earnings changes) for all firms in the sample, scaled by the cross sectional sum of lagged market equity. $E b$ (or $d E b$ ) is the cross-sectional sum of earnings (or earnings changes) for all firms in the 
sample, scaled by the cross sectional sum of lagged book value of equity. $E e$ (or $d E e$ ) is the cross-sectional sum of earnings (or earnings changes) for all firms in the sample, scaled by the cross sectional sum of lagged earnings. Following Kothari et al. (2006), we measure the portfolio values in three ways: The "Aggregate," denoted with a suffix_agg, numbers equal the sum of the numerator divided by the sum of the denominator for firms in the portfolio. The "Equal weighted" and "Value weighted, denoted with a suffix _ew and _vw respectively, numbers are instead averages of firm-level ratios, beginning with per share numbers. $d_{-} R_{t}^{\overline{e w}}\left(d_{-} R_{t}^{v w}\right)$ is the dummy variable taking 1 when $R_{t}^{e w}\left(R_{t}^{v w}\right)$ is less than zero, 0 otherwise. Our sample consists of firms with December fiscal year-end. We exclude stocks whose $d E p$ ratios fall in the top and bottom $1 \%$ of their annual distributions. ***, **, and * represent two-tailed significance at the $1 \%, 5 \%$, and $10 \%$ levels, respectively.

Table 4 Panel A presents the regression results for the Basu (1997) model with macroeconomic indicators when the gain/loss proxy is the equal-weighted market return. Only three out of twelve coefficients on the interaction variable remain significant and positive, and fewer intercepts are still significant. However, the adjusted $R^{2} \mathrm{~s}$ increase to the range of 0.02 and 0.58 from the range of -0.01 to 0.10 . These results are consistent with the model specification improvement with inclusion of the macroeconomic indicators. Panel B shows the regression results for the Basu model with macroeconomic indicators when value-weighted market return is used as the gain/loss proxy. Only two out of twelve regression coefficients on the interaction variable remain statistically significant. In both panels A and B some of the IPROD coefficients become significant, suggesting that industrial production explains aggregate accounting earnings to a certain degree.

Table 4. Aggregate-level Basu Models with macroeconomic indicators Panel A: Basu regressions using equal-weighted market return as the gain/loss proxy

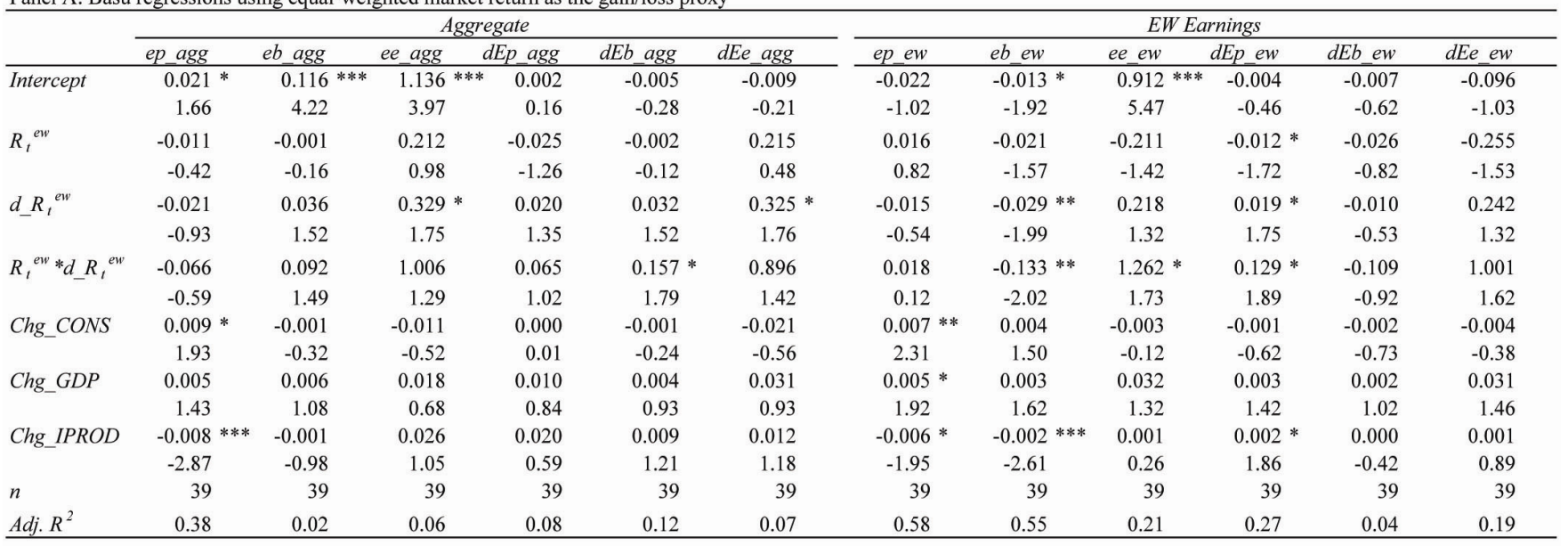

Panel B: Basu regressions using value-weighted market return as the gain/loss proxy

\begin{tabular}{|c|c|c|c|c|c|c|c|c|c|c|c|c|}
\hline & \multicolumn{6}{|c|}{ Aggregate } & \multicolumn{6}{|c|}{ VW Earnings } \\
\hline & ep agg & $e b$ agg & ee agg & $d E p$ agg & $d E b \quad a g g$ & dEe agg & $e p \quad v w$ & $e b v w$ & $e e v w$ & $d E p \quad v w$ & $d E b$ vw & $d E e v w$ \\
\hline \multirow[t]{2}{*}{ Intercept } & 0.011 & $0.225 * * *$ & $1.237 * * *$ & -0.003 & -0.009 & -0.052 & $0.013^{*}$ & 0.002 & $1.003 * *$ & -0.011 & -0.016 & 0.205 \\
\hline & 0.61 & 5.22 & 5.89 & -0.42 & -0.67 & -0.86 & 1.85 & 0.04 & 2.34 & -0.42 & -0.46 & 0.52 \\
\hline \multirow[t]{2}{*}{$R_{t}{ }^{v w}$} & 0.051 & 0.042 & 0.216 & -0.025 & 0.015 & 0.098 & 0.042 & -0.018 & -0.302 & -0.036 & 0.013 & -0.302 \\
\hline & 1.19 & 0.52 & 0.52 & -1.26 & 0.42 & 0.42 & 1.59 & -0.72 & -0.89 & -0.98 & 0.29 & -0.94 \\
\hline \multirow[t]{2}{*}{$d_{-} R_{t}{ }^{v w}$} & 0.012 & 0.037 & 0.261 & 0.006 & 0.032 & 0.216 & 0.006 & -0.015 & 0.062 & 0.005 & 0.026 & 0.159 \\
\hline & 0.58 & 1.52 & 1.49 & 0.92 & 1.29 & 1.52 & 1.24 & -0.52 & 0.33 & 0.52 & 1.09 & 1.52 \\
\hline \multirow[t]{2}{*}{$R_{t}{ }^{v w} \times d_{-} R_{t}{ }^{v w}$} & -0.062 & 0.072 & 0.325 & 0.082 & 0.049 & 0.179 & 0.021 & -0.018 & $1.546 * *$ & 0.062 & -0.019 & $2.104 *$ \\
\hline & -1.02 & 0.57 & 0.73 & 1.12 & 0.65 & 0.47 & 1.52 & -0.68 & 2.01 & 1.52 & -0.56 & 1.82 \\
\hline \multirow[t]{2}{*}{ Chg_CONS } & 0.004 & -0.001 & -0.007 & 0.001 & 0.000 & -0.005 & 0.002 & 0.010 & -0.098 & -0.002 & -0.001 & -0.062 \\
\hline & 1.48 & -0.52 & -0.26 & 0.55 & -0.08 & -0.79 & 1.29 & 1.12 & -1.45 & -0.25 & -0.62 & -1.25 \\
\hline \multirow[t]{2}{*}{ Chg_GDP } & $0.005 *$ & 0.004 & 0.026 & 0.001 & 0.001 & $0.013 *$ & $0.006 *$ & -0.001 & 0.058 & 0.003 & 0.004 & 0.061 \\
\hline & 1.72 & 1.52 & 0.69 & 0.64 & 0.79 & 1.78 & 1.79 & -0.62 & 1.26 & 1.03 & 1.06 & 1.21 \\
\hline \multirow[t]{2}{*}{ Chg_IPROD } & $-0.002 *$ & -0.001 & 0.011 & 0.000 & 0.002 & 0.006 & $-0.003 * *$ & 0.001 & 0.002 & 0.000 & 0.001 & 0.006 \\
\hline & -1.92 & -1.25 & 1.02 & 0.41 & 1.42 & 1.45 & -2.32 & 1.02 & 0.85 & 0.92 & 1.42 & 1.02 \\
\hline$n$ & 39 & 39 & 39 & 39 & 39 & 39 & 39 & 39 & 39 & 39 & 39 & 39 \\
\hline $\operatorname{Adj} . R^{2}$ & 0.44 & 0.04 & 0.06 & 0.11 & 0.09 & 0.07 & 0.48 & -0.02 & 0.11 & 0.10 & 0.06 & 0.14 \\
\hline
\end{tabular}

Note. This table reports the Basu regression with macroeconomic indicators at the aggregate-level. $R_{t}^{\text {ew }}$ measures the equal-weighted buy and hold market return from April of year $\mathrm{t}$ to March of year $\mathrm{t}+1 . R_{t}^{v w}$ measures the value-weighted buy and hold market return from April of year $\mathrm{t}$ to March of year $\mathrm{t}+1$. $E p$ (or $d E p$ ) is the cross-sectional sum of earnings (or earnings changes) for all firms in the sample, scaled by the cross sectional sum of 
lagged market equity. $E b$ (or $d E b$ ) is the cross-sectional sum of earnings (or earnings changes) for all firms in the sample, scaled by the cross sectional sum of lagged book value of equity. $E e$ (or $d E e$ ) is the cross-sectional sum of earnings (or earnings changes) for all firms in the sample, scaled by the cross sectional sum of lagged earnings. Following Kothari et al. (2006), we measure the portfolio values in three ways: The "Aggregate," denoted with a suffix _agg, numbers equal the sum of the numerator divided by the sum of the denominator for firms in the portfolio. The "Equal weighted" and "Value weighted, denoted with a suffix _ew and _vw respectively, numbers are instead averages of firm-level ratios, beginning with per share numbers. $d_{-} R_{t}^{\overline{e w}}\left(d_{-} R_{t}^{v{ }^{W}}\right)$ is the dummy variable taking 1 when $R_{t}^{e w}\left(R_{t}^{v w}\right)$ is less than zero, 0 otherwise. Chg_CONS is four quarter change in personal consumption. Chg_GDP is four quarter change in per capita growth rates of gross domestic product. Chg_IPROD is four quarter change in industrial production growth. Our sample consists of firms with December fiscal year-end. We exclude stocks whose $d E p$ ratios fall in the top and bottom $1 \%$ of their annual distributions. ***, **, and * represent two-tailed significance at the $1 \%, 5 \%$, and $10 \%$ levels, respectively.

Table 5 illustrates the regression results for the Basu (1997) model using macroeconomic indicators and discount rate proxies. Panels A and B show that the discount rates which have been missing from the earlier studies of conditional accounting conservatism at the aggregate level are important independent variables in explaining the variability of aggregate accounting earnings. Change in T-bill rate has a very strong positive coefficient across different regressions (eight out of twelve regressions), suggesting that aggregate accounting earnings are strongly and positively associated with change in the T-bill rate. This finding is consistent with the prior literature's argument that higher aggregate earnings are related to higher discount rates (i.e., Kothari et al. 2006; Patatoukas, 2014). Furthermore, the coefficient on the interaction variable $R_{t}^{e w} \times d R_{t}^{e w}$ is positively significant in nine out of twelve regressions with the inclusion of the discount rate variables. Finally, the adjusted $R^{2}$ increases in nine out of twelve regressions, consistent with $\mathrm{H} 2$.

Panel B of Table 5 reports the regression results for the Basu model with macroeconomic indicators and discount rate proxies when the gain/loss proxy is the value-weighted market return. Only four regression generates a positive coefficient on the interaction term at the marginal significance level. We suspect that this weak result is due to the difference between the distributions of equal-weighted versus value-weighted aggregate-level variables. Prior studies also report some differences in their empirical findings when they use both measurements (i.e., Kothari et al., 2006; Jorgensen et al., 2009). The change in the T-bill rate is still a significantly positive explanatory variable for aggregate earnings.

Table 5. Aggregate-level Basu Models with macroeconomic indicators and discount rates

Panel A: Basu regressions using equal-weighted market return as the gain/loss proxy

\begin{tabular}{|c|c|c|c|c|c|c|c|c|c|c|c|c|}
\hline & \multicolumn{6}{|c|}{ Aggregate } & \multicolumn{6}{|c|}{ EW Earnings } \\
\hline & $e p \_a g g$ & $e b \quad a g g$ & $e e \_a g g$ & $d E p \_a g g$ & $d E b \_a g g$ & $d E e$ agg & $e p \_e w$ & $e b \_w$ & ee_ew & $d E p \_e w$ & $d E b \_$ew & dEe ew \\
\hline \multirow[t]{2}{*}{ Intercept } & 0.013 & $0.154 * * *$ & $0.954 * * *$ & 0.007 & 0.021 & 0.092 & -0.019 & $-0.026 * *$ & $0.874 * * *$ & 0.007 & 0.003 & 0.052 \\
\hline & 1.19 & 4.46 & 9.01 & 1.26 & 1.51 & 1.27 & -1.26 & -1.98 & 5.52 & 1.23 & 0.29 & 0.92 \\
\hline \multirow[t]{2}{*}{$R_{t}{ }^{e w}$} & 0.002 & 0.029 & $0.242 *$ & 0.004 & 0.029 & $0.289 *$ & -0.021 & -0.021 & -0.091 & -0.011 & -0.021 & -0.172 \\
\hline & 0.26 & 1.01 & 1.69 & 0.42 & 1.28 & 1.82 & -0.83 & -1.39 & -1.52 & -0.52 & -0.75 & -1.26 \\
\hline \multirow{2}{*}{$d R_{t}{ }^{e w}$} & -0.007 & $0.051 *$ & $0.512 * * *$ & 0.031 & $0.058 * *$ & $0.502 * * *$ & -0.004 & -0.019 & $0.521 * * *$ & $0.026 * *$ & 0.002 & $0.416 * *$ \\
\hline & -0.62 & 1.71 & 3.15 & 1.62 & 2.55 & 4.41 & -0.27 & -1.62 & 2.62 & 2.11 & 0.11 & 2.48 \\
\hline \multirow[t]{2}{*}{$R_{t}{ }^{e w} \times d_{-} R_{t}{ }^{e w}$} & -0.011 & $0.302 *$ & $1.015 * * *$ & $0.121 * * *$ & $0.272 * * *$ & $1.026 * *$ & 0.048 & $-0.205 * *$ & $1.529 * *$ & $0.155 *$ & -0.101 & $1.275 * * *$ \\
\hline & -0.32 & 1.94 & 2.72 & 2.82 & 3.01 & 2.38 & 1.29 & -2.51 & 1.92 & 1.77 & -1.41 & 2.59 \\
\hline \multirow[t]{2}{*}{ Chg_CONS } & 0.005 & -0.001 & -0.031 & -0.001 & -0.003 & -0.031 & $0.009 * *$ & $0.007 * *$ & -0.026 & -0.010 & -0.001 & -0.051 \\
\hline & 1.63 & -0.42 & -1.36 & -0.71 & -0.71 & -1.52 & 2.44 & 2.04 & -0.89 & -0.92 & -0.74 & -1.02 \\
\hline \multirow[t]{2}{*}{ Chg_GDP } & 0.003 & 0.001 & 0.009 & 0.000 & 0.001 & 0.021 & 0.006 & 0.003 & $0.102 *$ & 0.001 & 0.004 & $0.047 *$ \\
\hline & 1.46 & 0.82 & 0.52 & 0.33 & 0.27 & 0.71 & 1.54 & 1.42 & 1.68 & 1.01 & 1.26 & 1.77 \\
\hline \multirow[t]{2}{*}{ Chg_IPROD } & $-0.004 *$ & -0.003 & -0.006 & -0.001 & 0.000 & -0.016 & $-0.006 * *$ & -0.003 & $-0.052 *$ & -0.002 & -0.001 & $-0.022 *$ \\
\hline & -1.91 & -1.02 & -0.81 & -1.02 & -0.39 & -0.98 & -2.24 & -1.42 & -1.86 & -0.89 & -0.26 & -1.70 \\
\hline \multirow[t]{2}{*}{ Chg_tbill } & 0.001 & $0.005 *$ & $0.069 * *$ & $0.009 * * *$ & $0.011 * * *$ & $0.082 * *$ & 0.002 & 0.000 & $0.079 * * *$ & $0.004 *$ & 0.007 & $0.081 * * *$ \\
\hline & 1.42 & 1.83 & 2.33 & 3.02 & 3.52 & 2.06 & 0.96 & 0.52 & 3.01 & 1.74 & 0.99 & 3.21 \\
\hline \multirow[t]{2}{*}{ Chg_TERM } & -0.002 & -0.001 & -0.002 & 0.004 & -0.001 & -0.003 & -0.001 & 0.001 & 0.039 & 0.001 & 0.004 & 0.055 \\
\hline & -1.35 & -0.59 & -0.52 & 0.61 & -1.42 & -0.16 & -0.59 & 0.82 & 1.55 & 0.59 & 0.61 & 1.43 \\
\hline \multirow[t]{2}{*}{ Chg_def } & 0.005 & 0.022 & $-0.192 *$ & -0.007 & -0.010 & -0.102 & $0.009 *$ & 0.005 & $-0.221 *$ & $-0.039 *$ & -0.005 & $-0.295 * *$ \\
\hline & 1.52 & 1.21 & -1.75 & -0.81 & -1.38 & -1.46 & 1.69 & 1.25 & -1.92 & -1.68 & -0.54 & -2.13 \\
\hline$n$ & 36 & 36 & 36 & 36 & 36 & 36 & 36 & 36 & 36 & 36 & 36 & 36 \\
\hline $\operatorname{Adj} . R^{2}$ & 0.51 & 0.17 & 0.38 & 0.43 & 0.44 & 0.40 & 0.53 & 0.41 & 0.41 & 0.45 & 0.02 & 0.40 \\
\hline
\end{tabular}


Panel B: Basu regressions using value-weighted market return as the gain/loss proxy

\begin{tabular}{|c|c|c|c|c|c|c|c|c|c|c|c|c|}
\hline & \multicolumn{6}{|c|}{ Aggregate } & \multicolumn{6}{|c|}{ VW Earnings } \\
\hline & $e p \_a g g$ & $e b \_a g g$ & $e e$ agg & dEp_agg & $d E b \_a g g$ & $d E e \_a g g$ & $e p \_v w$ & $e b \_v w$ & $e e \_v w$ & $d E p \_v w$ & $d E b \_v w$ & $d E e \_v w$ \\
\hline \multirow[t]{2}{*}{ Intercept } & 0.011 & $0.812 * * *$ & $1.116 * * *$ & 0.011 & 0.013 & 0.009 & 0.015 & -0.043 & $0.923 * * *$ & 0.013 & 0.006 & $0.419 *$ \\
\hline & 0.42 & 4.43 & 10.61 & 0.61 & 1.17 & 0.59 & 0.89 & -1.27 & 3.89 & 0.98 & 0.68 & 1.72 \\
\hline \multirow[t]{2}{*}{$R_{t}{ }^{v w}$} & $0.081 *$ & $0.091 *$ & 0.541 & 0.010 & 0.021 & $0.412 *$ & $0.044 *$ & -0.013 & -0.055 & -0.013 & 0.054 & -0.049 \\
\hline & 1.69 & 1.88 & 1.46 & 0.97 & 0.98 & 1.87 & 1.66 & -0.55 & -0.69 & -0.19 & 0.89 & -0.10 \\
\hline \multirow[t]{2}{*}{$d R_{t}{ }^{v w}$} & 0.021 & 0.241 & 0.634 & 0.024 & $0.039 *$ & $0.195 *$ & 0.008 & 0.015 & 0.215 & $0.020 *$ & 0.049 & 0.225 \\
\hline & 1.03 & 1.56 & 1.48 & 1.58 & 1.93 & 1.67 & 0.58 & 0.91 & 1.25 & 1.71 & 1.59 & 1.34 \\
\hline \multirow[t]{2}{*}{$R_{t}{ }^{v w} \times d_{-} R_{t}{ }^{v w}$} & -0.033 & $0.071 *$ & 0.283 & 0.031 & 0.051 & $0.281 *$ & -0.014 & -0.010 & $1.113 *$ & 0.061 & -0.019 & $1.148 *$ \\
\hline & -0.81 & 1.74 & 0.67 & 1.09 & 0.51 & 1.67 & -0.95 & -0.52 & 1.87 & 1.55 & -0.24 & 1.71 \\
\hline \multirow[t]{2}{*}{ Chg_CONS } & 0.005 & -0.002 & -0.009 & 0.001 & -0.001 & -0.009 & 0.004 & $0.003 *$ & -0.049 & -0.003 & 0.000 & -0.059 \\
\hline & 1.52 & -0.93 & -1.43 & 0.19 & -0.93 & -0.51 & 1.11 & 1.71 & -1.25 & -1.35 & -0.29 & -1.55 \\
\hline \multirow[t]{2}{*}{ Chg_GDP } & 0.004 & 0.001 & 0.008 & 0.000 & 0.001 & 0.008 & 0.004 & -0.003 & 0.038 & 0.000 & 0.002 & 0.010 \\
\hline & 1.32 & 0.31 & 0.93 & 0.63 & 0.64 & 1.12 & 1.35 & -0.79 & 0.96 & 0.35 & 0.89 & 0.75 \\
\hline \multirow[t]{2}{*}{ Chg_IPROD } & -0.002 & -0.001 & -0.010 & 0.001 & 0.001 & -0.003 & -0.002 & $0.003 * *$ & -0.010 & -0.002 & 0.000 & -0.004 \\
\hline & -1.62 & -0.97 & -0.59 & -0.55 & -0.90 & -0.32 & -1.13 & 1.98 & -1.04 & -0.54 & 0.45 & -1.26 \\
\hline \multirow[t]{2}{*}{ Chg_tbill } & $0.005 *$ & $0.015 * *$ & $0.062 * *$ & $0.005 * * *$ & $0.016 * *$ & $0.061 * *$ & 0.004 & -0.015 & $0.091 *$ & $0.016 * * *$ & $0.010 * *$ & $0.098 * *$ \\
\hline & 1.71 & 2.01 & 2.52 & 3.03 & 2.49 & 2.01 & 1.02 & -0.72 & 1.78 & 3.03 & 2.05 & 2.45 \\
\hline \multirow[t]{2}{*}{ Chg_TERM } & 0.001 & 0.002 & 0.031 & 0.005 & 0.000 & 0.009 & 0.002 & -0.001 & 0.091 & 0.010 & 0.001 & 0.017 \\
\hline & 0.81 & 0.42 & 1.35 & 0.89 & 0.49 & 1.35 & 0.73 & -0.67 & 1.05 & 1.35 & 0.28 & 0.89 \\
\hline \multirow[t]{2}{*}{ Chg_def } & 0.003 & 0.009 & $-0.168 *$ & -0.002 & $-0.013 *$ & -0.113 & 0.005 & 0.019 & -0.201 & -0.012 & -0.011 & -0.117 \\
\hline & 1.23 & 1.02 & -1.83 & -0.64 & -1.66 & -1.03 & 1.25 & 1.47 & -0.49 & -1.43 & -1.03 & -0.87 \\
\hline$n$ & 36 & 36 & 36 & 36 & 36 & 36 & 36 & 36 & 36 & 36 & 36 & 36 \\
\hline Adj. $R^{2}$ & 0.47 & 0.19 & 0.31 & 0.35 & 0.28 & 0.26 & 0.43 & 0.08 & 0.14 & 0.29 & 0.28 & 0.18 \\
\hline
\end{tabular}

Note. This table, Panel A (Panel B), reports the Basu regression with macroeconomic indicators and discount rate variables at the aggregate-level using equal-weighted (value-weighted) market return as the gain/loss proxy. $R_{t}^{\text {ew }}$ measures the equal-weighted buy and hold market return from April of year t to March of year $\mathrm{t}+1$. $R_{t}^{v w}$ measures the value-weighted buy and hold market return from April of year $\mathrm{t}$ to March of year $\mathrm{t}+1$. $E p$ (or $d E p$ ) is the cross-sectional sum of earnings (or earnings changes) for all firms in the sample, scaled by the cross sectional sum of lagged market equity. $E b$ (or $d E b$ ) is the cross-sectional sum of earnings (or earnings changes) for all firms in the sample, scaled by the cross sectional sum of lagged book value of equity. $E e$ (or $d E e$ ) is the cross-sectional sum of earnings (or earnings changes) for all firms in the sample, scaled by the cross sectional sum of lagged earnings. Following Kothari et al. (2006), we measure the portfolio values in three ways: The "Aggregate," denoted with a suffix_agg, numbers equal the sum of the numerator divided by the sum of the denominator for firms in the portfolio. The "Equal weighted" and "Value weighted, denoted with a suffix _ew and _vw respectively, numbers are instead averages of firm-level ratios, beginning with per share numbers. $d_{-} R_{t}^{{ }^{e} w}\left(d_{-} R_{t}{ }^{v \overline{ }}\right)$ is the dummy variable taking 1 when $R_{t}^{e w}\left(R_{t}^{v w}\right)$ is less than zero, 0 otherwise. Chg_CONS is four quarter change in personal consumption. Chg_GDP is four quarter change in per capita growth rates of gross domestic product. Chg_IPROD is four quarter change in industrial production growth. Chg_tbill is four quarter change in the 3-month T-bill rate. Chg_TERM is four quarter change in the yield spread between 10-year T-notes and 3-month T-bill rates. Chg_def is four quarter change in the yield spread between Baa- and Aaa-rated corporate bonds. Our sample consists of firms with December fiscal year-end. We exclude stocks whose $d E p$ ratios fall in the top and bottom $1 \%$ of their annual distributions. ***, **, and $*$ represent two-tailed significance at the $1 \%, 5 \%$, and $10 \%$ levels, respectively.

Table 6 presents the results for the Ball and Shivakumar (2006) modified accrual models. Panel A shows the results for the accruals models based on the modified Jones models and Panel B exhibits the results based on the modified Dechow and Dichev (2002) models. The intercepts for these regressions are all significantly negative. The coefficients on the change in revenues from Panel A are significantly positive at the $1 \%$ level consistent with of the modified Jones model predictions. There is also some evidence of a negative coefficient on gross PP\&E. In Panel B using the modified Dechow and Dichev (2002) model, we find that the coefficients on aggregate cash flows become significantly negative, consistent with the role of accruals in mitigating noise in cash flows. The lead- and lag-cash flows are generally positive, consistent with both Dechow and Dichev (2002) and Ball and Shivakumar's (2006) findings. However, the coefficient on the interaction variables $R_{t}^{e w} \times d R_{t}^{e w}$ and $R_{t}^{v w} \times d R_{t}^{v w}$ are insignificant across all regressions, inconsistent with conditional conservatism at the aggregate level. A possible explanation is that the insignificant interaction term derives from the negative correlation effect between innovations in aggregate accruals and market returns (i.e., Hirshleifer et al., 2009). In order to mitigate the potential problems caused by this negative correlation between innovations in aggregate accruals and market returns we use the change in cash flows as an alternative proxy for gain and loss. 
Table 6. Other conservatism models at aggregate-level using market return as the gain/loss proxy Panel A: Modified Jones Model

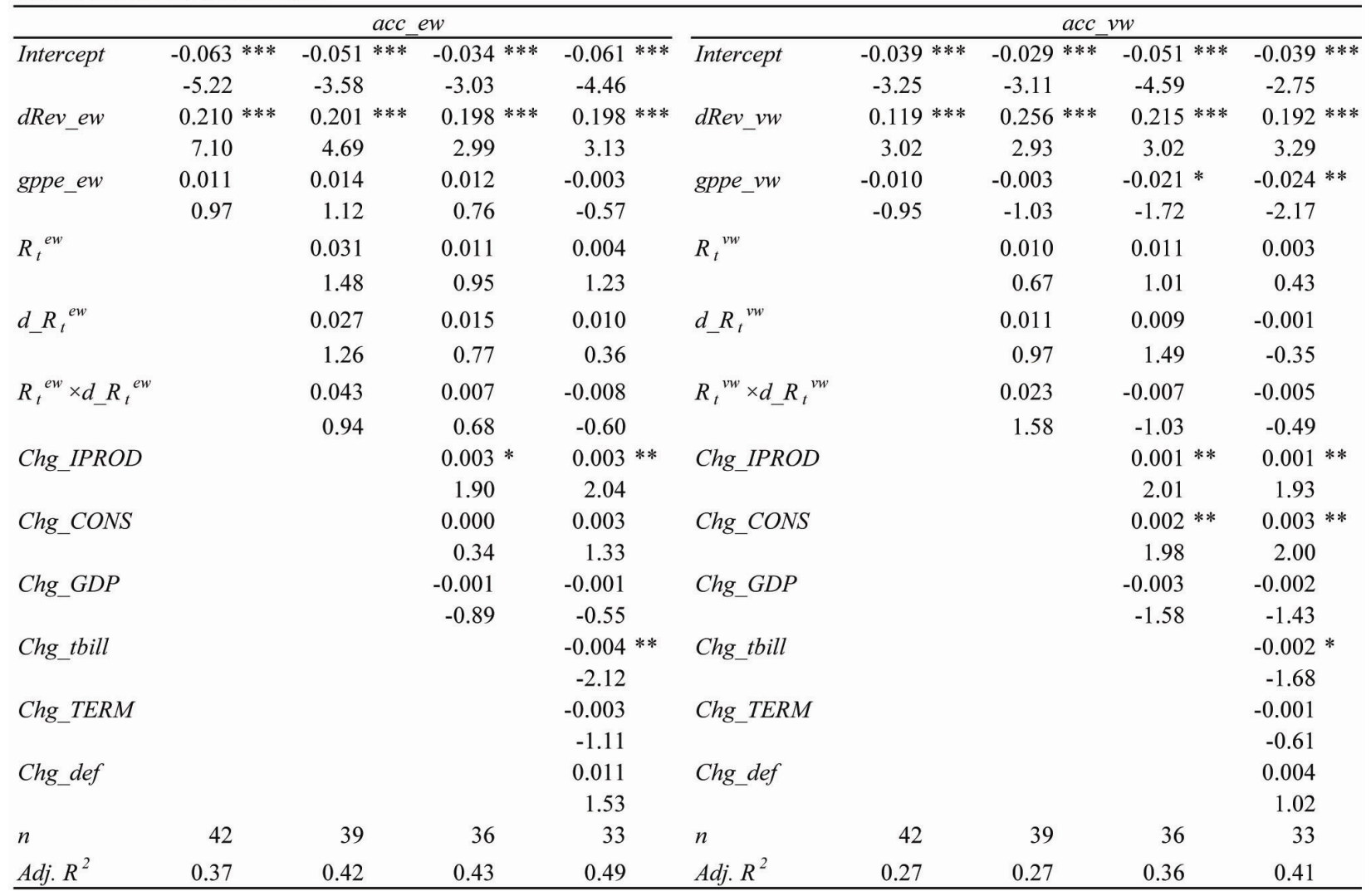

Note. This table, Panel A, reports the modified Jones regression with macroeconomic indicators and discount rate variables at the aggregate-level. Acc is the aggregate accruals. $d R e v$ is the aggregate revenue change and gppe is the aggregate gross PP\&E. $R_{t}^{e w}$ measures the equal-weighted buy and hold market return from April of year t to March of year $\mathrm{t}+1 . R_{t}^{v w}$ measures the value-weighted buy and hold market return from April of year $\mathrm{t}$ to March of year $\mathrm{t}+1$. $E p$ (or $d E p$ ) is the cross-sectional sum of earnings (or earnings changes) for all firms in the sample, scaled by the cross sectional sum of lagged market equity. $E b$ (or $d E b$ ) is the cross-sectional sum of earnings (or earnings changes) for all firms in the sample, scaled by the cross sectional sum of lagged book value of equity. Ee (or $d E e$ ) is the cross-sectional sum of earnings (or earnings changes) for all firms in the sample, scaled by the cross sectional sum of lagged earnings. Following Kothari et al. (2006), we measure the portfolio values in three ways: The "Aggregate," denoted with a suffix _agg, numbers equal the sum of the numerator divided by the sum of the denominator for firms in the portfolio. The "Equal weighted" and "Value weighted, denoted with a suffix _ew and _vw respectively, numbers are instead averages of firm-level ratios, beginning with per share numbers. $d_{-} R_{t}^{\text {ew }}\left(d_{-} R_{t}{ }^{\mathrm{v} w}\right)$ is the dummy variable taking 1 when $R_{t}^{e w}\left(R_{t}^{v w}\right)$ is less than zero, 0 otherwise. Chg_CONS is four quarter change in personal consumption. Chg_GDP is four quarter change in per capita growth rates of gross domestic product. Chg_IPROD is four quarter change in industrial production growth. Chg_tbill is four quarter change in the 3-month T-bill rate. Chg_TERM is four quarter change in the yield spread between 10-year T-notes and 3-month T-bill rates. Chg_def is four quarter change in the yield spread between Baa- and Aaa-rated corporate bonds. Our sample consists of firms with December fiscal year-end. We exclude stocks whose $d E p$ ratios fall in the top and bottom $1 \%$ of their annual distributions. $* * *, * *$, and $*$ represent two-tailed significance at the $1 \%, 5 \%$, and $10 \%$ levels, respectively. 
Panel B: Modified Dechow and Dichev Model

\begin{tabular}{|c|c|c|c|c|c|c|c|c|c|}
\hline \multirow[b]{2}{*}{ Intercept } & \multicolumn{4}{|c|}{$\operatorname{acc} e w$} & \multicolumn{5}{|c|}{$a c c \_v w$} \\
\hline & $\begin{array}{l}-0.152 * * * \\
-5.12\end{array}$ & $\begin{array}{l}-0.079 * * * \\
-3.25\end{array}$ & $\begin{array}{l}-0.035 * * \\
-2.31\end{array}$ & $\begin{array}{l}-0.041 * * * \\
-3.05\end{array}$ & Intercept & $\begin{array}{l}-0.077 * * * \\
-2.59\end{array}$ & $\begin{array}{l}-0.041 * * * \\
-2.61\end{array}$ & $\begin{array}{l}-0.031 * * \\
-2.22\end{array}$ & $\begin{array}{l}-0.027 * * \\
-2.32\end{array}$ \\
\hline cf_ew & $\begin{array}{l}-0.392 * * * \\
-2.64\end{array}$ & $\begin{array}{l}-0.388 * * \\
-2.46\end{array}$ & $\begin{array}{l}-0.442 * * * \\
-2.97\end{array}$ & $\begin{array}{l}-0.413 * * * \\
-2.59\end{array}$ & $c f \_v w$ & $\begin{array}{l}-0.401 * * * \\
-2.43\end{array}$ & $\begin{array}{l}-0.375 * * \\
-2.06\end{array}$ & $\begin{array}{l}-0.445 * * * \\
-2.89\end{array}$ & $\begin{array}{l}-0.414 * * * \\
-3.26\end{array}$ \\
\hline lag_cf_ew & $\begin{array}{l}0.339 * * * \\
2.59\end{array}$ & $\begin{array}{l}0.333 * * \\
2.52\end{array}$ & $\begin{array}{l}0.298 * * \\
2.32\end{array}$ & $\begin{array}{l}0.288 * * * \\
2.62\end{array}$ & lag_cf_vw & $\begin{array}{r}0.225 \\
0.99\end{array}$ & $\begin{array}{r}0.141 \\
1.07\end{array}$ & $\begin{array}{r}0.164 \\
1.22\end{array}$ & $\begin{array}{r}0.125 \\
1.54\end{array}$ \\
\hline lead_cf_ew & $\begin{array}{l}0.295^{* *} \\
1.99\end{array}$ & $\begin{array}{c}0.235 * \\
1.85\end{array}$ & $\begin{array}{c}0.199 * \\
1.71\end{array}$ & $\begin{array}{c}0.207 * \\
1.67\end{array}$ & lead_cf_vw & $\begin{array}{c}0.152 * \\
1.59\end{array}$ & $\begin{array}{l}0.236^{* *} \\
2.07\end{array}$ & $\begin{array}{c}0.199 * \\
1.83\end{array}$ & $\begin{array}{l}0.203 * * * \\
2.98\end{array}$ \\
\hline$R_{t}{ }^{e w}$ & & $\begin{array}{r}0.002 \\
0.21\end{array}$ & $\begin{array}{r}-0.003 \\
-0.62\end{array}$ & $\begin{array}{r}0.040 \\
0.62\end{array}$ & $R_{t}^{v w}$ & & $\begin{array}{r}0.003 \\
0.56\end{array}$ & $\begin{array}{r}-0.002 \\
-0.51\end{array}$ & $\begin{array}{r}0.004 \\
0.65\end{array}$ \\
\hline$d_{-} R_{t}{ }^{e w}$ & & $\begin{array}{r}0.021 \\
1.59\end{array}$ & $\begin{array}{r}0.015 \\
0.85\end{array}$ & $\begin{array}{r}0.049 \\
1.44\end{array}$ & $d_{-} R_{t}{ }^{v w}$ & & $\begin{array}{r}0.000 \\
0.33\end{array}$ & $\begin{array}{r}-0.002 \\
-0.66\end{array}$ & $\begin{array}{r}0.001 \\
0.36\end{array}$ \\
\hline$R_{t}{ }^{e w} \times d_{-} R_{t}{ }^{e w}$ & & $\begin{array}{r}0.081 \\
0.94\end{array}$ & $\begin{array}{r}0.037 \\
1.12\end{array}$ & $\begin{array}{r}0.036 \\
0.79\end{array}$ & $R_{t}{ }^{v w} \times d_{-} R_{t}{ }^{v w}$ & & $\begin{array}{r}-0.031 \\
-1.12\end{array}$ & $\begin{array}{r}-0.063 \\
-1.13\end{array}$ & $\begin{array}{r}-0.063 \\
-1.45\end{array}$ \\
\hline Chg_IPROD & & & $\begin{array}{r}0.002 \\
0.34\end{array}$ & $\begin{array}{r}0.001 \\
0.72\end{array}$ & Chg_IPROD & & & $\begin{array}{r}0.001 \\
1.55\end{array}$ & $\begin{array}{r}0.001 \\
1.34\end{array}$ \\
\hline Chg_CONS & & & $\begin{array}{r}0.001 \\
0.26\end{array}$ & $\begin{array}{r}0.001 \\
0.66\end{array}$ & Chg_CONS & & & $\begin{array}{r}0.002 \\
1.14\end{array}$ & $\begin{array}{l}0.002 * * \\
1.99\end{array}$ \\
\hline Chg_GDP & & & $\begin{array}{r}0.002 \\
1.03\end{array}$ & $\begin{array}{r}0.001 \\
0.79\end{array}$ & Chg_GDP & & & $\begin{array}{r}0.002 \\
0.88\end{array}$ & $\begin{array}{l}0.000 \\
-0.18\end{array}$ \\
\hline Chg_tbill & & & & $\begin{array}{c}0.001 * \\
1.68\end{array}$ & Chg_tbill & & & & $\begin{array}{r}0.001 \\
1.64\end{array}$ \\
\hline Chg_TERM & & & & $\begin{array}{r}-0.001 \\
-0.43\end{array}$ & Chg_TERM & & & & $\begin{array}{l}0.000 \\
-0.67\end{array}$ \\
\hline Chg_def & & & & $\begin{array}{c}0.021 * \\
1.82\end{array}$ & Chg_def & & & & $\begin{array}{l}0.074 \text { ** } \\
2.13\end{array}$ \\
\hline$n$ & 41 & 38 & 35 & 32 & $n$ & 41 & 38 & 35 & 32 \\
\hline $\operatorname{Adj} \cdot R^{2}$ & 0.25 & 0.26 & 0.36 & 0.43 & Adj. $R^{2}$ & 0.16 & 0.18 & 0.30 & 0.39 \\
\hline
\end{tabular}

Note. This table, Panel B, reports modified Dechow and Dichev regression with macroeconomic indicators and discount rate variables at the aggregate-level. Acc is the aggregate accruals. $d R e v$ is the aggregate revenue change and gppe is the aggregate gross PP\&E. $R_{t}^{e w}$ measures the equal-weighted buy and hold market return from April of year $\mathrm{t}$ to March of year $\mathrm{t}+1 . R_{t}^{v w}$ measures the value-weighted buy and hold market return from April of year $\mathrm{t}$ to March of year $\mathrm{t}+1$. $E p$ (or $d E p$ ) is the cross-sectional sum of earnings (or earnings changes) for all firms in the sample, scaled by the cross sectional sum of lagged market equity. $E b$ (or $d E b$ ) is the cross-sectional sum of earnings (or earnings changes) for all firms in the sample, scaled by the cross sectional sum of lagged book value of equity. Ee (or $d E e$ ) is the cross-sectional sum of earnings (or earnings changes) for all firms in the sample, scaled by the cross sectional sum of lagged earnings. Following Kothari et al. (2006), we measure the portfolio values in three ways: The "Aggregate," denoted with a suffix _agg, numbers equal the sum of the numerator divided by the sum of the denominator for firms in the portfolio. The "Equal weighted" and "Value weighted, denoted with a suffix _ew and _vw respectively, numbers are instead averages of firm-level ratios, beginning with per share numbers. $d_{-} R_{t}^{e \bar{w}}\left(d_{-} R_{t}^{v w}\right)$ is the dummy variable taking 1 when $R_{t}^{e w}\left(R_{t}^{v w}\right)$ is less than zero, 0 otherwise. Chg_CONS is four quarter change in personal consumption. Chg_GDP is four quarter change in per capita growth rates of gross domestic product. Chg_IPROD is four quarter change in industrial production growth. Chg_tbill is four quarter change in the 3-month T-bill rate. Chg_TERM is four quarter change in the yield spread between 10-year T-notes and 3-month T-bill rates. Chg_def is four quarter change in the yield spread between Baa- and Aaa-rated corporate bonds. Our sample consists of firms with December fiscal year-end. We exclude stocks whose $d E p$ ratios fall in the top and bottom $1 \%$ of their annual distributions. $* * *, * *$, and $*$ represent two-tailed significance at the $1 \%, 5 \%$, and $10 \%$ levels, respectively.

Table 7 reports the result for the Ball and Shivakumar (2006) modified accruals models using change in cash flows $d C F$ as the gain/loss proxy. When using the equal-weighted $d C F_{t}$ measure as the gain/loss proxy both the modified Jones models and the Dechow and Dichev (2002) models convey conditional conservatism. In both panels A and B, the coefficient on the interaction term int $d C F \_$_w becomes statistically significant and positive in regressions in which accruals are equal-weighted, consistent with the conditional conservatism in accruals recognition for bad news versus good news. 
Table 7. Other conservatism models at aggregate-level using change in cash flows as the gain/loss proxy

Panel A: Modified Jones Model

\begin{tabular}{|c|c|c|c|c|c|c|c|c|c|}
\hline \multirow[b]{2}{*}{ Intercept } & \multicolumn{4}{|c|}{$a c c e w$} & & \multicolumn{4}{|c|}{$a c c v w$} \\
\hline & $\begin{array}{l}-0.063 * * * \\
-5.22\end{array}$ & $\begin{array}{l}-0.048 * * * \\
-3.32\end{array}$ & $\begin{array}{l}-0.039 * * * \\
-4.16\end{array}$ & $\begin{array}{l}-0.037^{* * *} \\
-2.69\end{array}$ & Intercept & $\begin{array}{l}-0.039 * * * \\
-3.25\end{array}$ & $\begin{array}{l}-0.030 * * * \\
-3.98\end{array}$ & $\begin{array}{c}-0.027 \\
-2.44\end{array}$ & $\begin{array}{c}-0.029 * * \\
-2.21\end{array}$ \\
\hline dRev_ew & $\begin{array}{c}0.210 * * * \\
7.10\end{array}$ & $\begin{array}{l}0.203 * * * \\
5.64\end{array}$ & $\begin{array}{l}0.222 * * * \\
3.34\end{array}$ & $\begin{array}{c}0.192 * * * \\
4.11\end{array}$ & $d R e v \_v w$ & $\begin{array}{l}0.119 * * * \\
3.02\end{array}$ & $\begin{array}{l}0.156 * * * \\
2.79\end{array}$ & $\begin{array}{l}0.197 * * * \\
3.11\end{array}$ & $\begin{array}{l}0.191 \text { *** } \\
2.85\end{array}$ \\
\hline gppe_ew & $\begin{array}{r}0.011 \\
0.97\end{array}$ & $\begin{array}{r}0.014 \\
1.54\end{array}$ & $\begin{array}{c}0.009 * \\
1.72\end{array}$ & $\begin{array}{c}0.007 \text { * } \\
1.69\end{array}$ & gppe_vw & $\begin{array}{r}-0.010 \\
-0.95\end{array}$ & $\begin{array}{r}-0.008 \\
-1.12\end{array}$ & $\begin{array}{c}-0.014 * \\
-1.79\end{array}$ & $\begin{array}{l}-0.021 * * \\
-2.13\end{array}$ \\
\hline$d C F \_e w$ & & $\begin{array}{c}-0.434 * * \\
-2.07\end{array}$ & $\begin{array}{l}-0.729 * * * \\
-3.32\end{array}$ & $\begin{array}{c}-0.540 * \\
-1.92\end{array}$ & $d C F \_v w$ & & $\begin{array}{c}-0.397 \text { * } \\
-1.71\end{array}$ & $\begin{array}{c}-0.330 * \\
-1.82\end{array}$ & $\begin{array}{l}-0.291 * * \\
-1.99\end{array}$ \\
\hline$d \_d C F \_e w$ & & $\begin{array}{r}0.004 \\
1.22\end{array}$ & $\begin{array}{r}0.005 \\
1.43\end{array}$ & $\begin{array}{r}0.013 \\
1.36\end{array}$ & $d \_d C F \_v w$ & & $\begin{array}{r}-0.004 \\
-0.77\end{array}$ & $\begin{array}{r}-0.003 \\
-0.99\end{array}$ & $\begin{array}{c}-0.004 * \\
-1.71\end{array}$ \\
\hline int_dCF_ew & & $\begin{array}{c}0.640 * * \\
1.99\end{array}$ & $\begin{array}{c}0.651 * \\
1.77\end{array}$ & $\begin{array}{c}0.442 * \\
1.68\end{array}$ & int_dCF_vw & & $\begin{array}{r}0.283 \\
1.02\end{array}$ & $\begin{array}{r}0.132 \\
0.62\end{array}$ & $\begin{array}{r}0.176 \\
0.91\end{array}$ \\
\hline Chg_IPROD & & & $\begin{array}{r}0.001 \\
0.90\end{array}$ & $\begin{array}{c}0.001 \\
1.99\end{array}$ & Chg_IPROD & & & $\begin{array}{c}0.002 * * * \\
2.91\end{array}$ & $\begin{array}{c}0.003 \text { ** } \\
2.12\end{array}$ \\
\hline Chg_CONS & & & $\begin{array}{r}0.002 \\
1.39\end{array}$ & $\begin{array}{r}0.001 \\
0.59\end{array}$ & Chg_CONS & & & $\begin{array}{c}0.002 * \\
1.75\end{array}$ & $\begin{array}{c}0.002 \\
1.98\end{array}$ \\
\hline Chg_GDP & & & $\begin{array}{r}0.000 \\
0.33\end{array}$ & $\begin{array}{r}-0.001 \\
-0.72\end{array}$ & Chg_GDP & & & $\begin{array}{c}-0.003 \\
-1.68\end{array}$ & $\begin{array}{c}-0.003 * \\
-1.94\end{array}$ \\
\hline Chg_tbill & & & & $\begin{array}{r}-0.001 \\
-0.22\end{array}$ & Chg_tbill & & & & $\begin{array}{r}-0.002 \\
-1.62\end{array}$ \\
\hline Chg_TERM & & & & $\begin{array}{l}0.000 \\
-0.31\end{array}$ & Chg_TERM & & & & $\begin{array}{r}-0.001 \\
-1.44\end{array}$ \\
\hline Chg_def & & & & $\begin{array}{c}0.014 * \\
1.78\end{array}$ & Chg_def & & & & $\begin{array}{r}0.007 \\
1.03\end{array}$ \\
\hline$n$ & 42 & 39 & 36 & 33 & $n$ & 42 & 39 & 36 & 33 \\
\hline $\operatorname{Adj} . R^{2}$ & 0.37 & 0.50 & 0.56 & 0.60 & Adj. $R^{2}$ & 0.27 & 0.32 & 0.50 & 0.51 \\
\hline
\end{tabular}

This table, Panel A, reports modified Jones regression with macroeconomic indicators and discount rate variables at the aggregate-level using change in cash flows at the gain/loss proxy. $A c c$ is the aggregate accruals. $d C F \_e w$ and $d C F_{-} v w$ are the aggregate cash flows change, equal- and value-weighted respectively. $d R e v$ is the aggregate revenue change and gppe is the aggregate gross PP\&E. $d \_d C F$ is the dummy variable taking 1 when $d C F$ is less than zero, 0 otherwise. int $d C F$ is the interaction term between $d C F$ and $d_{-} d C F$. Following Kothari et al. (2006), we measure the portfolio values in three ways: The "Aggregate," denoted with a suffix _agg, numbers equal the sum of the numerator divided by the sum of the denominator for firms in the portfolio. The "Equal weighted" and "Value weighted, denoted with a suffix _ew and _vw respectively, numbers are instead averages of firm-level ratios, beginning with per share numbers. Chg_CONS is four quarter change in personal consumption. Chg_GDP is four quarter change in per capita growth rates of gross domestic product. Chg IPROD is four quarter change in industrial production growth. Chg_tbill is four quarter change in the 3-month T-bill rate. Chg_TERM is four quarter change in the yield spread between 10-year T-notes and 3-month T-bill rates. Chg_def is four quarter change in the yield spread between Baa- and Aaa-rated corporate bonds. Our sample consists of firms with December fiscal year-end. We exclude stocks whose $d E p$ ratios fall in the top and bottom $1 \%$ of their annual distributions. ***, **, and * represent two-tailed significance at the $1 \%, 5 \%$, and $10 \%$ levels, respectively. 
Panel B: Modified Dechow and Dichev model

\begin{tabular}{|c|c|c|c|c|c|c|c|c|c|}
\hline \multirow[b]{2}{*}{ Intercept } & \multicolumn{4}{|c|}{ acc ew } & & \multicolumn{4}{|c|}{$\operatorname{acc} v w$} \\
\hline & $-0.152 * * *$ & $-0.062 * * *$ & $-0.049 * *$ & $-0.033 * *$ & Intercept & $-0.077 * * *$ & $-0.051 *$ & $-0.015 *$ & $-0.021 *$ \\
\hline & -5.12 & -2.69 & -2.51 & -2.02 & & -2.59 & -1.81 & -1.72 & -1.89 \\
\hline \multirow[t]{2}{*}{$c f \_w$} & $-0.392 * * *$ & $-0.377 * *$ & $-0.801 * * *$ & $-0.684 * * *$ & $c f \_v w$ & $-0.401 * * *$ & $-0.602 * *$ & $-0.819 * * *$ & $-0.713 * *$ \\
\hline & -2.64 & -2.10 & -4.03 & -3.92 & & -2.43 & -2.27 & -2.59 & -2.44 \\
\hline \multirow[t]{2}{*}{ lag_cf_ew } & $0.339 * * *$ & $0.592 * * *$ & $0.612 *$ & $0.549 * *$ & lag_cf_vw & 0.225 & $0.398 *$ & $0.498 *$ & $0.299 *$ \\
\hline & 2.59 & 2.00 & 1.71 & 2.43 & & 0.99 & 1.89 & 2.05 & 1.89 \\
\hline \multirow[t]{2}{*}{ lead_cf_ew } & $0.295 * *$ & $0.232 *$ & $0.282 *$ & $0.198 *$ & lead_cf_vw & $0.152 *$ & $0.211 * *$ & 0.103 & $0.156 * *$ \\
\hline & 1.99 & 1.78 & 1.77 & 1.73 & & 1.59 & 2.27 & 1.54 & 2.10 \\
\hline \multirow[t]{2}{*}{$d \_d C F \_w$} & & 0.006 & 0.005 & 0.005 & $d \_d C F \_v w$ & & -0.002 & -0.003 & -0.002 \\
\hline & & 1.38 & 0.99 & 1.48 & & & -1.00 & -0.94 & -1.04 \\
\hline \multirow[t]{2}{*}{ int_dCF_ew } & & $0.899 *$ & $0.819 *$ & $0.803 *$ & int_dCF_vw & & 0.403 & 0.499 & 1.011 \\
\hline & & 1.82 & 1.94 & 1.75 & & & 1.02 & 1.34 & 1.63 \\
\hline \multirow[t]{2}{*}{ Chg_IPROD } & & & 0.001 & 0.000 & Chg_IPROD & & & -0.001 & 0.000 \\
\hline & & & 0.72 & 0.94 & & & & -1.15 & -0.62 \\
\hline \multirow[t]{2}{*}{ Chg_CONS } & & & 0.002 & 0.002 & Chg_CONS & & & 0.001 & 0.002 \\
\hline & & & 0.81 & 0.88 & & & & 0.95 & 1.12 \\
\hline \multirow[t]{2}{*}{ Chg_GDP } & & & 0.001 & 0.001 & Chg_GDP & & & 0.001 & 0.000 \\
\hline & & & 1.26 & 0.29 & & & & 0.79 & -0.54 \\
\hline \multirow[t]{2}{*}{ Chg_tbill } & & & & 0.001 & Chg_tbill & & & & $0.002 *$ \\
\hline & & & & 1.43 & & & & & 1.74 \\
\hline \multirow[t]{2}{*}{ Chg_TERM } & & & & -0.001 & Chg_TERM & & & & -0.002 \\
\hline & & & & -0.72 & & & & & -1.32 \\
\hline \multirow[t]{2}{*}{ Chg_def } & & & & $0.009 *$ & Chg_def & & & & $0.010 *$ \\
\hline & & & & 1.79 & & & & & 1.71 \\
\hline$n$ & 41 & 39 & 36 & 33 & $n$ & 41 & 39 & 36 & 33 \\
\hline Adj. $R^{2}$ & 0.25 & 0.32 & 0.39 & 0.44 & Adj. $R^{2}$ & 0.16 & 0.23 & 0.29 & 0.33 \\
\hline
\end{tabular}

Note. This table, Panel B, reports modified Dechow and Dichew regression with macroeconomic indicators and discount rate variables at the aggregate-level using change in cash flows at the gain/loss proxy. Acc is the aggregate accruals. $d C F \_$ew and $d C F \_v w$ are the aggregate cash flows change, equal- and value-weighted respectively. $d R e v$ is the aggregate revenue change and gppe is the aggregate gross PP\&E. $d \_d C F$ is the dummy variable taking 1 when $d C F$ is less than zero, 0 otherwise. int $d C F$ is the interaction term between $c f$ and $d \_d C F$. Following Kothari et al. (2006), we measure the portfolio values in three ways: The "Aggregate," denoted with a suffix agg, numbers equal the sum of the numerator divided by the sum of the denominator for firms in the portfolio. The "Equal weighted" and "Value weighted, denoted with a suffix _ew and _vw respectively, numbers are instead averages of firm-level ratios, beginning with per share numbers. Chg_CONS is four quarter change in personal consumption. Chg_GDP is four quarter change in per capita growth rates of gross domestic product. Chg IPROD is four quarter change in industrial production growth. Chg_tbill is four quarter change in the 3-month T-bill rate. Chg_TERM is four quarter change in the yield spread between 10-year T-notes and 3-month T-bill rates. Chg_def is four quarter change in the yield spread between Baa- and Aaa-rated corporate bonds. Our sample consists of firms with December fiscal year-end. We exclude stocks whose $d E p$ ratios fall in the top and bottom $1 \%$ of their annual distributions. ***, ${ }^{* *}$, and * represent two-tailed significance at the $1 \%, 5 \%$, and $10 \%$ levels, respectively.

\section{Conclusion}

We examine conditional accounting conservatism at the aggregate level using both the Basu (1997) and Ball and Shivakumar (2006) models. We find some evidence consistent with conditional accounting conservatism at the aggregate level. Our results show that the sensitivity of aggregate accounting earnings to equal-weighted aggregate market returns is approximately three times as high in periods with negative aggregate returns as is in periods with positive aggregate returns. Our results also show that the inclusion of macroeconomic indicators and discount rate variables into the conditional accounting conservatism models improves the model specification. For example, when equal-weighted return is used as a gain/loss proxy the inclusion of macroeconomic indicators and discount rate proxies into the regression model increases the adjusted $R^{2}$ from $5 \%$ to $53 \%$. Based on the empirical evidence from this study, we recommend that researchers who study the fundamental characteristics of accounting information in the context of aggregate accounting earnings include both macroeconomic indicators and discount rate variables as explanatory variables in their regression models in order to improve model specification and explanatory power. Our findings are consistent with the argument that an efficient market requires that aggregate accounting earnings recognize losses in a timelier manner than gains (refer to Shivakuma 2007 \& 2010).

This study contributes to the literature as follows. First, using both the Basu (1997) and Ball and Shivakumar (2006) 
models we document empirical evidence of conditional accounting conservatism at the aggregate level. Second, we demonstrate that adding macroeconomic indicators and discount rate variables into the "reverse regression models" for accounting earnings and returns at the aggregate level improves the model specification significantly. More importantly, our findings show that conditional accounting conservatism is still visible even after controlling for the relationship between the aggregate returns and discount rate. Third, our results add to the aggregate studies by showing that aggregate accruals are timelier in recognizing bad relative to good economic news at the aggregate level, suggesting that firms do manage accounting accruals in response to market-wide undervaluation. We therefore conclude that conditional accounting conservatism is a property of aggregate earnings, contrary to earlier studies.

However, our empirical tests are at most tests of joint hypotheses. That is, our hypotheses $H 1 a$ and $H 1 b$ are also a test of the assumption that our market gain/loss proxies, i.e., equal- and value-weighted market returns and change in cash flows, truly measure the underlying characteristic of aggregate level news. Future studies may consider different proxies for market gains/losses to test conditional accounting conservatism at aggregate level.

\section{Acknowledgements}

We thank the editor and the three anonymous referrers for their constructive comments and suggestions. We also benefited from helpful comments and discussions from workshop participants at the University of Texas at Dallas and Idaho State University. We appreciate financial supports from Idaho State University's College of Business and University at Buffalo's School of Management.

\section{References}

Anilowski, C., Feng, M., \& Skinner, D. (2006). Does earnings guidance affect market returns? The nature and information content of aggregate earnings guidance. Journal of Accounting and Economics, 44 (1-2), 36-63. http://dx.doi.org/10.1016/j.jacceco.2006.09.002

Ball, R., \& Brown, P. (1968). An empirical evaluation of accounting income numbers. Journal of Accounting Research, 6, 159-178. http://dx.doi.org/10.2307/2490232

Ball, R., Robin, A., \& Sadka, G. (2008). Is financial reporting shaped by equity markets or by debt markets? An international study of timeliness and conservatism. Review of Accounting Studies, 13, 168-205. http://dx.doi.org/10.1007/s11142-007-9064-x

Ball, R., Sadka, G., \& Sadka, R. (2009). Aggregate earnings and asset prices. Journal of Accounting Research, 47, 1097-1134. http://dx.doi.org/10.1111/j.1475-679X.2009.00351.x

Ball, R., \& Shivakumar, L. (2006). The role of accruals in asymmetrically timely gain and loss recognition. Journal of Accounting Research, 44 (2), 207-242. http://dx.doi.org/10.1111/j.1475-679X.2006.00198.x

Basu, S. (1997). The conservatism principle and the asymmetric timeliness of earnings. Journal of Accounting and Economics, 24, 3-37. http://dx.doi.org/10.1016/S0165-4101(97)00014-1

Beaver, W. (1968). The information content of annual earnings announcements. Journal of Accounting Research, 6 , 67-92. http://dx.doi.org/10.2307/2490070

Bernard, V., \& Thomas, J. (1990). Evidence that stock prices do not fully reflect the implications of current earnings for future earnings. Journal of Accounting and Economics, 13, 305-340. http://dx.doi.org/10.1016/0165-4101(90)90008-R

Bliss, J. (1924). Management through Accounts. New York, NY: The Ronald Press Co.

Brown, P., \& Ball, R. (1967). Some preliminary findings on the association between the earnings of a firm, its industry, and the economy. Journal of Accounting Research, 5 (supplement), 55-77. http://dx.doi.org/10.2307 12489908

Campbell, J. (1991). A variance decomposition for stock returns. Economic Journal, 101, 157-179. http://dx.doi.org $/ 10.2307 / 2233809$

Caskey, J., \& Peterson, K. (2014). Conservatism measures that control for the effects of economic rents on stock returns. Review of Quantitative Finance and Accounting, 42, 731-756. http://dx.doi.org/10.1007/s11156-013-0360-1

Crawley, M. (2014). Macroeconomic consequences of accounting: The effect of accounting conservatism on macroeconomic indicators and the money supply. Working Paper, Indiana University.

Cready, W., \& Gurun, U. (2010). Aggregate market reaction to earnings announcements. Journal of Accounting Research, 48 (2), 289-334. http://dx.doi.org/10.1111/j.1475-679X.2010.00368.x

Dechow, P., \& Dichev, I. (2002). The quality of accruals and earnings: The role of accrual estimation errors. The Accounting Review, 77 (supplement), 35-59. http://dx.doi.org/10.2308/accr.2002.77.s-1.35

Fama, E., \& French, K. (1989). Business conditions and expected returns on stocks and bonds. Journal of Financial Economics, 25, 23-49. http://dx.doi.org/10.1016/0304-405X(89)90095-0 
Flannery, M., \& Protopapadakis, A. (2002). Macroeconomic factors do influence aggregate stock returns. Review of Financial Studies, 15, 751-782. http://dx.doi.org/10.1093/rfs/15.3.751

Givoly, D., Hayn, C., \& Natarajan, A. (2007). Measuring reporting conservatism. The Accounting Review, 82 (1), 65-106. http://dx.doi.org/10.2308/accr.2007.82.1.65

Gkougkousi, X., (2014). Aggregate earnings and corporate bond markets. Journal of Accounting Research, 52 (1), 75-106. http://dx.doi.org/10.1111/1475-679X.12030

Hirshleifer, D., Kewei, H., \& Teoh, S. (2009). Accruals, cash flows, and aggregate stock returns. Journal of Financial Economics, 91, 389-406. http://dx.doi.org/10.1016/j.jfineco.2007.11.009

Hribar, P., \& Collins, D. (2002). Errors in estimating accruals: Implications for empirical research. Journal of Accounting Research, 40 (1), 105-134. http://dx.doi.org/10.1111/1475-679X.00041

Jones, J. (1991). Earnings management during import relief investigations. Journal of Accounting Research, 29, 193-228. http://dx.doi.org/10.2307/2491047

Jorgensen, B., Li, J., \& Sadka, G. (2009). Are accounting standards diversifiable? Evidence of the aggregate valuation effects of standards. Working paper, The University of Colorado at Boulder.

Jorgensen, B., Li, J., \& Sadka, G. (2012). Earnings dispersion and aggregate stock returns. Journal of Accounting and Economics, 53, 1-20. http://dx.doi.org/10.1016/j.jacceco.2011.06.001

Konchitchki, Y., \& Patatoukas, P. (2013). Taking the pulse of the real economy using financial statement analysis: Implications for macro forecasting and stock valuation. The Accounting Review, 89 (2), 669-694. http://dx.doi.org/10.2308/accr-50632

Konchitchki, Y., \& Patatoukas, P. (2014). Accounting earnings and gross domestic product. Journal of Accounting and Economics, 57, 76-88. http://dx.doi.org/10.1016/j.jacceco.2013.10.001

Kothari, S.P., Lewellen, J., \& Warner, J. (2006). Stock returns, aggregate earnings surprises, and behavioral finance. Journal of Financial Economics, 79, 537-568. http://dx.doi.org/10.1016/jfineco.2004.06.016

LaFond, R., \& Roychowdhury, S. (2008). Managerial ownership and accounting conservatism. Journal of Accounting Research, 46, 101-135. http://dx.doi.org/10.1111/j.1475-679X.2008.00268.x

Lamont, O. (1998). Earnings and expected returns. Journal of Finance, 53, 1563-1587. http://dx.doi.org/10.1111 /0022-1082.00065

Lobo, G., \& Zhou, J. (2006). Did conservatism in financial reporting increase after the Sarbanes-Oxley Act? Initial evidence. Accounting Horizons, 20 (1), 57-73. http://dx.doi.org/10.2308/acch.2006.20.1.57

Newey, W., \& West, K. (1987). A simple, positive semi-definite, heteroscedasticity and autocorrelation consistent covariance matrix. Econometrica, 55, 703-708. http://dx.doi.org/10.2307/1913610

Patatoukas, P. (2014). Detecting news in aggregate accounting earnings: Implications for stock market valuation. Review of Accounting Studies, 19, 134-160. http://dx.doi.org/10.1007/s11142-013-9221-3

Penman, S. (1987). The distribution of earnings news over time and seasonalities in aggregate stock returns. Journal of Financial Economics, 18, 199-228. http://dx.doi.org/10.1016/0304-405X(87)90039-0

Qiang, X. (2007). The effects of contracting, litigation, regulation, and tax costs on conditional and unconditional conservatism: Cross-sectional evidence at the firm level. The Accounting Review, 82 (3), 759-796. http://dx.doi.org/10.2308/accr.2007.82.3.759

Sadka, G., \& Sadka, R. (2009). Predictability and the earnings-return relation. Journal of Financial Economics, 94, 87-106. http://dx.doi.org/10.1016/j.jfineco.2008.10.005

Shivakumar, L. (2007). Aggregate earnings, stock market returns and macroeconomic activity: A discussion of “does earnings guidance affect market returns? The nature and information content of aggregate earnings guidance. Journal of Accounting and Economics, 44, 64-73. http://dx.doi.org/10.1016/j.jacceco.2006.12.001

Shivakumar, L. (2010). Discussion of aggregate market reaction to earnings announcements. Journal of Accounting Research, 48 (2), 335-342. http://dx.doi.org/10.1111/j.1475-679X.2010.00369.x

Sloan, R. (1996). Do stock prices fully reflect information in accruals and cash flows about future earnings? The Accounting Review, 71 (3), 289-315.

Watts, R. (2003). Conservatism in accounting part I: Explanations and implications. Accounting Horizons, 17 (3), 207-221. http://dx.doi.org/10.2308/acch.2003.17.3.207

Zhang, J. (2008). The contracting benefits of accounting conservatism to lenders and borrowers. Journal of Accounting and Economics, 45, 27-54. http://dx.doi.org/10.1016/j.jacceco.2007.06.002 